\title{
ANALISIS SANAD DAN MATANHADIS TENTANG KEUTAMAAN BULAN RAMADAN (DIBELENGGUNYA SETAN-SETAN)
}

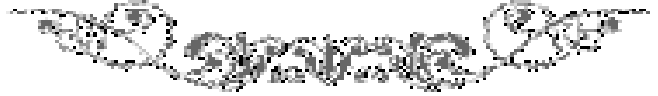 \\ AAS ASARI \\ Jurusan Ilmu Alquran dan Tafsir \\ Institut Agama Islam Negeri Syekh Nurjati Cirebon
}

\begin{abstract}
In months Ramadan, all people struggle to keep their fasting. The governments also really pay attention to fasting activity in months Ramadan. The public phenomenon has been doing the sin in months Ramadan is the problem that should to watch. What are the people in the world doing the sin because of only devil temptation? Or are there the other factors that make the people dong the sin? The goals of this research is to obtain the data of hadis accurately about the superiority in months Ramadan (the devils handcuffed) by this hadis, is the hadist can be a hujjah or not?. After doing this research by using qualitative approach, literature method, and descriptive, also using the sanad and matan criticism theory, it can be concluded that the hadis of the months Ramadan superiority about the devils handcuff is able to the new knowledge. The hadis that explain about the superiority of months Ramadan (the devils handcuffed) the entire narrated strip based on the quality of this hadis initially include in the criteria of Sahih hadis, except the hadis that narrated by Imam Al-Nasa'i on the fourth sanad schema included in the da'if category because broken the sanad from Ubaidillah, Ya'qub, Ibrahim, Ibnu Ishaq, Ibnu Shihab, and Ibnu Abi Anas which should from Ibnu Abi Anas to Abu Anas, in this sanad strip directly to Abu Hurairah. Besides, there is a friend to jarh claimed that as suduq yudallis by Ibnu Hajar is Muhammad bin Ishaq. Although there is broke sanad strip, but this hadis reinforced with the other hadis strip such as narrated strip of Imam An-Nasai and other mukharij in order to degree of the hadis raise become sahịh li ghairihi hadis. Meanwhile, based on the quantitiy this hadis included into ahad gharib hadis that initially affected by only one person to narrate, he is Abu Hurairah. But, quantity of the hadis is change become ahad gharib hadis because every narrator thabaqah increased. The meaning of hadis about the superiority of months Ramadan (the devils handcuffed) has two real meanings. The hadis interpreted
\end{abstract}


obviously that the devils really handcuffed obviously. Second meaning is majazi which the meaning is only analogy the devils are not handcuffed, but the devils cannot disturb people that doing the fasting.

Keywords: Ramadan, Hadis, and Majazi

\section{PENDAHULUAN}

Hadis merupakan sumber hukum kedua setelah Alquran. ${ }^{1}$ Alquran dan hadis ialah dua sumber hukum Islam yang tetap. Manusia tidak mungkin memahami syariat Islam secara mendalam tanpa kembali dan merujuk kepada kedua sumber hukum Islam tersebut. Banyak ayat Alquran dan hadis yang menegaskan bahwa hadis merupakan sumber hukum Islam selain Alquran yang harus diikuti, baik dalam bentuk perintah ataupun larangannya. ${ }^{2}$

Nabi Muhammad Saw hidup di tengah-tengah masyarakat dan sahabatnya. Pergaulan dengan Nabi setiap hari tidak ada yang membatasinya. Seluruh perbuatan Nabi, begitu juga dengan ucapan dan tutur kata yang dilakukan menjadi tumpuan perhatian bagi masyarakat pada waktu itu terutama para sahabat. ${ }^{3}$ Segala gerak-gerik yang dilakukan Nabi menjadi tauladan dalam menjalani kehidupan. Berdasarkan kepada kesungguhan meniru dan meneladani semua yang dilakukan Nabi, sehingga mendapatkan gelar uswatun hasanah (tauladan yang baik). Ketika Nabi wafat, para sahabatlah yang membawa panji-panji Islam, meneruskan perjalanan Nabi dalam menyampaikan risalah. ${ }^{4}$

Riwayat yang sampai sekarang masih dijadikan sumber hukum ini, tidak terlepas dari usaha para sahabat Nabi. Para sahabat menerima suatu hadis dari Nabi adakalanya langsung, yakni sahabat mendengar sendiri dari Nabi, karena ada suatu soal atau permasalahan yang ditanyakan oleh seseorang kemudian Nabi menjawabnya. Terkadang Nabi sendiri yang menjelaskan suatu hukum sehingga para sahabat menyimaknya dengan baik. Selain itu juga, para sahabat menerima hadis dari Nabi tidak secara langsung bertatap muka atau mendengar langsung. Sahabat menerima dari sesama sahabat sendiri yang telah menerima langsung dari Nabi. Adanya hal seperti

${ }^{1}$ Ahmad Abdul Khozin, Pengantar Ulumul Hadis (Cirebon: STAI BBC, 2012), 7.

2 Teungku Muhammad Hasbi ash-Shiddieqy, Sejarah dan Pengantar Ilmu Hadis (Semarang: Pustaka Rizqi Putra, 1999), 21.

3 Teungku Muhammad Hasbi ash-Shiddieqy, Sejarah dan Pengantar Ilmu Hadis, 27.

${ }^{4}$ Nuruddin 'Itr, Ulumul Hadis (Bandung: Remaja Rosdakarya, 2012), 25. 
ini ditandai bahwasannya penyampaian hadis oleh Nabi dengan cara lisan yang disampaikan kepada para sahabat. ${ }^{5}$

Perbuatan, perkataan, dan ketentuan Nabi merupakan informasi yang sangat penting yang disampaikan oleh para sahabat kepada generasi selanjutnya. ${ }^{6}$ Tujuan dari adanya suatu berita dari Nabi agar tingkah laku manusia berpegang teguh kepada Alquran dan hadis. Di antara kandungan hadis Nabi adalah yang berkaitan dengan hal yang gaib, yang tidak dapat dilihat oleh mata telanjang. Akan tetapi semua itu harus diimani karena hal yang gaib benar ada. ${ }^{7}$ Agama melalui wahyu ilahi mengungkap seluk beluk tentang makhluk gaib, di antaranya adalah Jin.

Jin merupakan penghuni bumi yang mempunyai tugas seperti manusia, yaitu beribadah. Manusia dan Jin mempunyai perbedaan yaitu manusia tidak dapat melihatnya akan tetapi Jin dapat melihat manusia. Di antara Jin, yaitu Setan dan Iblis yang pernah melakukan sumpah kepada Allah untuk menyesatkan semua manusia. ${ }^{8}$ Iblis juga mempunyai keistimewaan dibandingkan dengan makhluk yang lainnya, yaitu tidak akan mati sampai datangnya kiamat. Meskipun mempunyai kelebihan tapi akan abadi di Neraka. Terjadinya hal ini dikarenakan kesombongan Iblis ketika menolak untuk bersujud kepada Nabi Adam.

Allah menjadi sangat murka ketika Iblis bersikap sombong dan takabur. Allah mengusir Iblis dari surga untuk turun ke bumi. Akan tetapi Iblis meminta dipanjangkan umurnya sampai hari kiamat dan Allah mengabulkannya. Setelah itu, akhirnya Iblis turun ke Bumi. Sebagaimana firman Allah dalam surat al-A'rāf ayat 13 yang ditafsirkan oleh Kementerian Agama RI adalah sebagai berikut. ${ }^{9}$

"Setelah Allah melihat tingkah laku Iblis yang menyombongkan diri, karena menganggap bahwa dia lebih mulia dari Adam. Yang menyebabkan dia durhaka dan membangkang dan tidak taat pada perintah-Nya, maka ia diperintah oleh Allah agar turun dari surga, tempat ia berada waktu itu, karena tampat itu adalah diperuntukkan bagi hamba-hamba-Nya yang ikhlas dan rendah hati dan bukanlah tempat untuk memperlihatkan keangkuhan dan kesombongan."

\footnotetext{
${ }^{5}$ Muhammad Alfatih Suryadilaga, Aplikasi Penelitian Hadis (Yogyakarta: Teras, 2009), 5 .

${ }^{6}$ Yunahar Ilyas dan Muhammad Mas'ud, Perkembangan Pemikiran Terhadap Hadis (Yogyakarta: LPPI, 1996), 53.

7 Amr Abdul Mun'im Salim, Taysir Ulum al-Hadis lil Mubtadi'in (Kairo: Maktabah Ibnu Taymiyah, 1997), 11.

${ }^{8}$ Cyrill Glasse, Ensiklopedia Islam (Jakarta: Rajawali Press, 1999), 23. 2012), jilid 3, 307.

${ }^{9}$ Kementerian Agama RI, Alquran dan Tafsir (Jakarta: Kementerian Agama RI,
} 
Iblis menjadi musuh yang nyata bagi manusia dan berusaha mencari pengikut yang lebih banyak, baik dari kalangan manusia ataupun Jin. Oleh karena itu, barang siapa yang mengikuti jejak Iblis atau Setan maka akan dimasukan ke dalam Neraka. Iblis dan Setan merupakan nama yang paling terkenal dikalangan manusia. Mendengar kata Setan atau iblis tergambarkan dalam benak merupakan puncaknya kejahatan. Kata Iblis ini sudah dipahami oleh manusia, sebagai lambang kejahatan bahkan wujud dari kejahatan itu. Sehingga Iblis atau Setan itu seolah-olah mempunyai sifat indperawi dan nyata, bukan imajinasi dan abstrak. ${ }^{10}$

Manusia dalam bertingkah laku sehari-hari digoda oleh Setan, terutama masalah ibadah. Setan menggoda manusia dalam beribadah baik salat, puasa atau ibadah yang lainnya. Tiap detik manusia melakukan suatu ibadah tidak akan terlepas dari godaan Setan. Hanya orang-orang yang mempunyai iman yang kuat yang dapat terhindar dari gangguan dan rayuan Setan. Sehingga kata Setan sendiri mempunyai arti sebagai penggoda, pemberi kewaswasan dan penjerumus kesesatan. ${ }^{11}$

Setiap kali manusia melakukan suatu perbuatan, di situ juga Setan siap untuk menggoda, akan tetapi di bulan Ramadan manusia dapat terhindar dari Setan. Karena di bulan yang suci ini Setan dibelenggu atau dirantai oleh Allah. Hal ini membuktikan sebagai bentuk dari keutamaan bulan Ramadan. Sebagaimana Nabi bersabda :

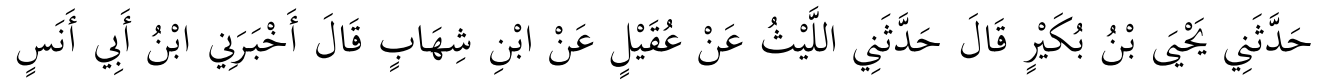

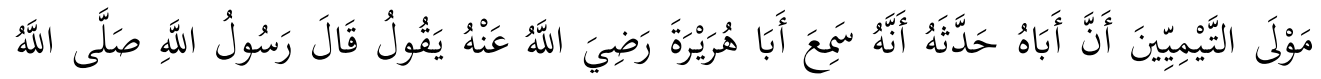

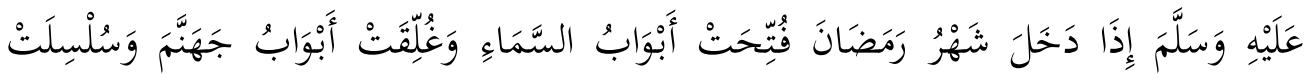
الشَّيَاطِينُ (رواه البخاري)

"Telah menceritakan kepada kami Yahya bin Bukair berkata, telah menceritakan kepada saya al-Layth dari 'Uqayl dari Ibnu Shihāb berkata, telah mengabarkan kepada saya Ibnu Abū Anas, maulanya at-Taymiyyin bahwa bapaknya menceritakan kepadanya bahwa dia mendengar Abu Hurairah r.a berkata, Rasulullah Saw bersabda: "Apabila bulan Ramadan datang, maka pintu-pintu langit dibuka

${ }^{10}$ M. Quraish Shihab, Yang Tersembunyi (Lentera Hati: Jakarta, 2000), 92.

${ }^{11}$ M. Quraish Shihab, Yang Tersembunyi, 87. 


\section{sedangkan pintu-pintu jahannam ditutup dan Setan-setan dibelenggu". (HR. Al-Bukhārī)}

Hadis di atas merupakan salah satu keterangan yang menerangkan keutamaan bulan Ramadan. Adapun kandungan hadis ini bahwa di bulan suci Ramadan manusia terhindar dari godaan/gangguan Setan. Penyebab manusia terhindar dari godaan tersebut adalah karena Setan-setan semua dibelenggu. Akan tetapi semua ini bertentangan dengan fakta yang ada dalam kehidupan masyarakat. Manusia di bulan suci Ramadan masih ada saja yang melakukan dosa, misalnya seorang Muslim seharusnya berpuasa tapi tidak berpuasa, seharusnya salat malah sebaliknya. Bahkan perbuatan dosa yang dilakukan oleh manusia di bulan Ramadan sangat merajalela dibandingkan di bulan yang lainnya.

Semua kalangan di bulan Ramadan berusaha menjaga ibadah puasanya. Aparat pemerintah sangat memperhatikan kegiatan puasa di bulan Ramadan. Tempat-tempat $c l u b$ malam misalnya cafe, diskotek dan tempat hiburan yang lainnya di batasi waktu dalam operasinya bahkan ada yang ditutup selama satu bulan. Begitu juga dengan ormas Islam sangat berperan penting dalam membasmi kemaksiatan. Akan tetapi, dibalik semua itu masih banyak warung remang-remang yang buka siang hari dengan pelanggan yang banyak juga. Ironisnya pelanggan tersebut adalah orang Muslim. Kejadian ini membuktikan bahwa eksistensi Setan masih berperan untuk menggoda manusia.

Adanya penomena masyarakat yang masih melakukan dosa di bulan Ramadan adalah masalah yang harus diperhatikan. Apakah semua manusia melakukan dosa itu karena godaan Setan semata ? ataukah ada faktor lain yang membuat manusia melakukan dosa ? sekalipun Setan-setan dibelenggu tapi masih banyak yang berbuat kejahatan di bulan Ramadan ini.

\section{HASIL DAN PEMBAHASAN}

\section{A. Gambaran Bulan Ramadan}

\section{Pengertian Ramadan}

Ramadan adalah bulan diturunkannya Alquran, sebagai panduan untuk umat manusia, juga tanda yang jelas untuk bimbingan dan penilaian (antara benar dan salah). Selanjutnya, jika salah seorang dari manusia yang beriman mencapai bulan itu, maka diwajibkan berpuasa. Sebagaimana firman Allah dalam Q.S. Al-Baqarah ayat 183:

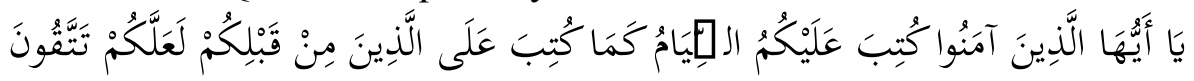


"Hai orang-orang yang beriman, diwajibkan atas kamu berpuasa sebagaimana diwajibkan atas orang-orang sebelum kamu agar kamu bertakwa"."

Ramadan bulan kesembilan dalam kalender Islam, adalah bulan yang paling penting dan suci bagi umat Islam. Ayat-ayat pertama Alquran diturunkan pada bulan ini. Allah menginginkan Muslim untuk menunaikan puasa pada bulan ini dan seperti yang dinyatakan dalam hadis yang menjelaskan bahwa Allah (SWT) memberikan lebih banyak pahala untuk ibadah dan rahmat di bulan tersebut. ${ }^{13}$ Para Ulama mengatakan bahwa Ramadan adalah sebuah bulan yang berlimpah dan mulia yang dapat membuat seorang Muslim menghargai dan menghabiskan waktu dengan ibadah, memperoleh pahala sebanyak pahala ibadah 80 tahun. ${ }^{14}$

Kata Ramadan mengandung makna yang berarti "membakar". Selain itu juga Ramadan adalah kata dari bahasa Arab yang mempunyai kata dasar "Ramaḍa". Kata Ramaḍa artinya semakin panas, karena panas yang terus menerus dan tanah yang menjadi semakin panas sedemikian rupa disebut "Ramḍa". ${ }^{15}$ Jadi Ramadan artinya membakar atau untuk membakar, karena berjalan telanjang kaki di tanah yang hangus. Alasan mengapa bulan suci ini disebut "Ramadan" adalah karena ia membakar dosa. Pada bulan Ramadan, seorang Muslim yang berpuasa menahan panas karena kelaparan dan haus dan panasnya puasa membakar dosa-dosa. ${ }^{16}$

Menurut Elmalili Hamdi Yazir, Ramadan berarti "hujan", Ramadan berasal dari kata dasar "Ramadiiyu" yang berarti "hujan" yang terlihat pada akhir musim panas, pada awal musim gugur dan membersihkan bumi dari debu. Seperti hujan yang mencuci permukaan bumi, bulan Ramadan mensucikan orang beriman dari dosa dan membersihkan hati manusia. Diceritakan bahwa Ramadan adalah salah satu dari Asma (Nama) Allah Yang Indah. Anas Bin Malik meriwayatkan dari Nabi Muhammad Saw yang tercinta bahwa jangan panggil (bulan suci) hanya "Ramadan". Ulama RI, 2012)

${ }^{12}$ Kementerian Agama RI, Alquran dan Terjemahan (Jakarta: Kementerian Agama

13 Nogarsah Moede Gaya, Buku Pintar Islam (Jakarta: Ladang Pustaka dan Intimedia, t.th), 380 .

${ }^{14}$ Makmun Jamaludin, Ramadan Bulan Mulia (Bandung: CV. Kurnia Asih, 2011), 45.

15 Dewan Redaksi Ensiklopedi Islam, Ensiklopedi Islam (Jakarta: PT. Intermas, 1999), 145.

${ }^{16}$ Ahmad Syarifudin, Puasa Menuju Sehat Fisik dan Psikis (Jakarta: Gema Insan, 2003), 16. 
mengatakan bahwa "Ramadan" adalah salah satu nama Allah. Jadi, bulan ini harus disebut sebagai Shahri Ramadan (bulan Ramadan). ${ }^{17}$

Imam Al-Bukhāri menuliskan sebuah bab dalam kitab Sahịh -nya dengan judul "apakah diucapkan Ramadan atau bulan Ramadan”. Mengenai hal ini, ada tiga pendapat di kalangan ulama. ${ }^{18}$

a. Tidak boleh mengatakan Ramadan tetapi harus bulan Ramadan. Sebagian ulama mengatakan bahwa tidak boleh menyebut kata Ramadan kecuali disertai dengan kata bulan, yakni bulan Ramadan. Pendapat ini dikemukakan Ața dan Mujāhid. Kedua imam ini tidak mengucapkan Ramadan. Dan lebih senang mengucapkan bulan Ramadan karena bisa jadi Ramadan adalah salah satu nama dari nama-nama Allah. ${ }^{19}$

b. Boleh menyebut Ramadan jika ada indikasi yang mengarah kepada bulan. Jika tidak ada indikasi itu maka hukumnya makruh. Boleh mengatakan kami telah melaksanakan salat malam Ramadan, atau Ramadan adalah bulan yang paling utama. Namun tidak boleh mengatakan telah datang Ramadan atau telah masuk Ramadan dan kalimat lain yang sejenis. Karena dikhawatirkan akan dipahami bahwa Allah yang datang dan Allah yang masuk. Mengingat Ramadan sebagaimana disebutkan dalam hadis adalah salah satu asma Allah. ${ }^{20}$

c. Boleh mengatakan Ramadan atau mengatakan bulan Ramadan. Pendapat inilah yang dipilih para ulama peneliti, diantara mereka adalah Imam al-Bukhāri. Jadi boleh mengucapkan Ramadan atau mengucapkan bulan Ramadan dan sama sekali tidak ada kemakruhan. Karena hadis yang melarang itu sangat lemah, sedang Rasulullah sendiri telah mengucapkan kedua istilah itu dalam banyak hadis.

Pada bulan yang istimewa ini, terdapat sekian banyak wahana yang bisa dimanfaatkan dalam rangka penggemblengan dan pemanasan diri. Dari yang wajib hingga yang sunah seperti tadarus, taperawih, sedekah dan sebagainya. Wahana yang tersedia yang bermacam-macam ini sesuai dengan nama bulan Ramadan yang lain. Tinggal apakah ada kemauan untuk melakukan proses penggemblengan dengan sebaik-baiknya, santai atau justru keluar dari proses penggemblengan atas dasar kemerdekaan yang

${ }^{17}$ Ahmad Syarifudin, Puasa Menuju Sehat Fisik dan Psikis, 31.

18 Azhari Nuruddin, Bulan Ramadan Yang Dirindukan (Bandung: Pustaka Cempaka, 2015), 5.

${ }^{19}$ Azhari Nuruddin, Bulan Ramadan Yang Dirindukan, 8.

${ }^{20}$ Azhari Nuruddin, Bulan Ramadan Yang Dirindukan, 10. 
diimpikan. ${ }^{21} \mathrm{Di}$ antara nama-nama bulan Ramadan yang menunjukkan suatu pengertian dari wahana tertentu adalah sebagai berikut: $:^{22}$

a. Shahru al-Siyām, bulan puasa, bulan pengendalian diri dari hal-hal yang dilarang.

b. Shahru al-Khair, Ramadan dinamakan bulan kebaikan karena pada bulan itu Allah menurunkan limpahan kebaikan sejak hari pertama hingga hari akhir. Karenanya limpahan kebaikan di bulan ini hendaknya memberikan inspirasi kepada manusia untuk banyak berbuat kebaikan.

c. Shahru al-Barakah, Ramadan juga dinamakan bulan keberkahan ${ }^{23}$, karena pada bulan ini Allah melimpahkan berkah yang luar biasa. Rasulullah bersabda yang artinya "Wahai manusia telah menaungi kalian bulan agung, bulan yang penuh berkah, bulan yang didalamnya terdapat suatu malam yang lebih baik dari pada seribu bulan. Allah menjadikan puasa di bulan ini hukumnya wajib dan menjadikan salat malam di bulan ini hukumnya sunah, barang siapa mendekatkan diri kepada Allah dengan suatu amalan sunah di bulan ini, maka sama dengan orang yang melaksanakan satu amalan wajib di bulan lain.

d. Shahru Alquran, bulan yang di dalamnya diturunkan Alquran. Imam Baihaqi berkata, diserukan untuk memperbanyak tilawah Alquran di bulan Ramadan karena bulan itu adalah bulan Alquran. Adapun tentang kepastian malam dimulainya wahyu itu tanggal 17 Ramadan, karena bertemunya dua pasukan besar, ialah pada tanggal tersebut, tahun kedua hijrah. Yang dimaksud dua pasukan besar adalah kaum Muslimin dan kaum musyrikin di Badar.

e. Shahru al-Mubārak, bulan yang penuh berkah. Rezeki orang mukmin meningkat dan lancar. Amal-amal kebajikan dinilai ganda.

f. Shahru al-A'la', bulan yang penuh kenikmatan

g. Shahru at-Tiläwah, bulan membaca Alquran atau bulan menekuni diri untuk memahami makna Alquran.

h. Shahru al-Sabri, bulan kesabaran. Ulama berpendapat bahwa bulan kesabaran adalah bulan Ramadan. Makna kesabaran adalah menahan diri. Puasa dinamakan kesabaran karena di dalamnya terdapat kewajiban untuk menahan diri dari makan dan minum, serta mencegahnya dari berhubungan seksual dengan istri di siang harinya. Bahkan semua bentuk kesabaran terhimpun dalam puasa. Ulama

\footnotetext{
${ }^{21}$ Ahmad Syarifudin, Puasa Menuju Sehat Fisik dan Psikis, 17.

${ }^{22}$ Ahmad Syarifudin, Puasa Menuju Sehat Fisik dan Psikis, 18.

${ }^{23}$ Nasarudin Umar, Jihad (Tebet Barat: Mata Air Publising, 2006), 73.
} 
berkata sabar ada tiga macam,;2 sabar dalam melaksanakan ketaatan kepada Allah, sabar dalam meninggalkan hal-hal yang diharamkan allah, sabar atas takdir allah yang menyakitkan. Ketiga macam sabar ini terhimpun dalam puasa. Karena dalam puasa terdapat kesabaran dalam melaksanakan ketaatan kepada Allah, kesabaran dalam meninggalkan keinginan dan syahwat yang diharamkan Allah, dan sabar atas penderitaan yang dialami orang yang berpuasa seperti lapar, dahaga, kelemahan fisik dan jiwa. Sedang kesabaran, pahalanya akan diberikan secara penuh oelh Allah tanpa perhitungan. Allah berfirman sebagai berikut:

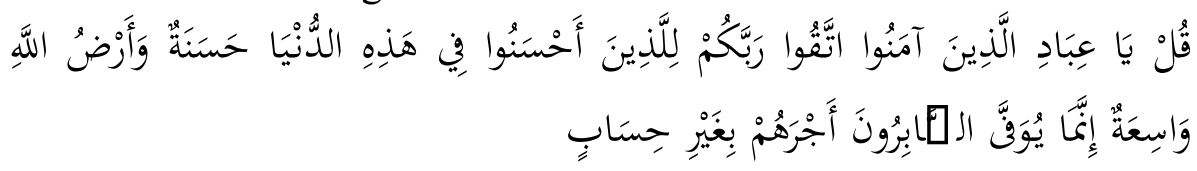

"Katakanlah: "Hai hamba-hamba-Ku yang beriman. bertakwalah kepada Tuhanmu". orang-orang yang berbuat baik di dunia ini memperoleh kebaikan. dan bumi Allah itu adalah luas. Sesungguhnya hanya orang-orang yang bersabarlah yang dicukupkan pahala mereka tanpa batas". (Q.S. Al-Zumar: 10) ${ }^{25}$

i. Shahru al-Rahmah, bulan kasih sayang. Limpahan kasih sayang Allah yang amat banyak kepada manusia. Sebagai kompensasinya manusia harus menampakkan kasih sayang kepada sesama makhluk-Nya.

j. Shahru al-Muwasah, bulan kedermawanan atau bulan sosial. Ramadan dinamakan bulan Muwasah (bulan pertolongan), karena bulan itu manusia diperintah untuk membantu dan menolong orang yang membutuhkan pertolongan. Diharuskan untuk menolong orang lain meskipun hanya dengan satu biji kurma ataupun seteguk air, karena Allah membalasnya dengan limpahan pahala diakhirat dan keberkahan hidup didunia.

k. Shahru al-Najah, bulan keselamatan dari azab Neraka.

1. Shahru al-Jüd, bulan bermurah tangan, memberi bantuan kepada fakir miskin.

2. Nilai Pahala Ibadah di Bulan Ramadan

Ramadan adalah jamak dari Ramadanāt atau armiḍa. Menurut pengertian bahasa Ramadan berarti sangat panas. Nama Ramadan ini disebut oleh orang-orang Arab pada bulan yang kesembilan dari hitungan hijriah.

\footnotetext{
${ }^{24}$ Lutfhi Bashori, Musuh Besar Islam (Jakarta: LPPI, 2006), 53. RI, 2012).

${ }^{25}$ Kementerian Agama RI, Alquran dan Terjemahan (Jakarta: Kementerian Agama
} 
Alasan diartikan sangat panas karena pada bulan ini biasanya padang pasir panas karena teriknya matahari. Perihal yang lain juga bahwa adat istiadat atau kebiasaan orang-orang Arab dulu dengan satu istilah kepada bahasa orang-orang Arab tersebut yang disesuaikan dengan keadaan yang terjadi pada masa itu. Contohnya pada bulan kesembilan ini udara sangatlah panas, maka bulan tersebut bangsa Arab menyebutnya dengan nama Ramadan. ${ }^{26}$

Kata Ramadan adalah sebuah nama bulan yang kesembilan dari hitungan hijriah yang mempunyai arti sangat panas. Pendapat ini berbeda dengan keterangan di atas, bahwa alasan mempunyai arti panas karena pada zaman dulu bangsa Arab mempunyai kebiasaan yang sangat khas, yaitu kaum jahiliah sering memanaskan senjata mereka diterik matahari. Mempersiapkan diri untuk berperang dalam bulan Syawal apabila diserang. ${ }^{27}$

Ramadan juga sering disebut bulan yang penuh berkah. Kata berkah sendiri mengandung arti ziyādah al-Khair maksudnya tambahan kebaikan atau multi manfaat. Hal ini dikaitkan dengan bulan Ramadan yang mana di dalamnya mengandung beberapa hal yang diceritakan oleh Nabi di antaranya yaitu: 28

a. Nafas-nafas orang yang berpuasa di bulan Ramadan adalah dihitung sebagai tasbih. Maksudnya, bahwa orang yang berpuasa di bulan Ramadan nafasnya dikatakan ibadah, berbeda dengan bulan yang lainnya. Dikatakan sebuah ibadah lisan yang mendatangkan pahala yang luar biasa. Apalagi disaat orang tersebut mengucapkan tasbih kepada Allah disetiap tarikan dan hembusan nafas. Menurut para ahli bahasa bahwa kata tasbih pada awalnya bermakna menjauh. Oleh karena itu, orang berenang disebut dengan saabih katena menjauhi tempat asal berada. Maksud bertasbih disini bukan hanya saja membaca tasbih akan tetapi mensucikan Allah dan menjauhkan prasangka kepada Allah dari sifat yang buruk itulah yang kemudian dinamakan sebagai tasbih. ${ }^{29}$

Ucapan subhāanallah harus diikuti dengan niat dalam hati sebagai upaya untuk menjauhkan atau mensucikan Allah dari penisbahanpenisbahan keburukan kepada-Nya. Tasbih ini yang akan lebih bermakna dan melipat gandakan pahala jika melakukannya setiap saat di bulan Ramadan.

${ }^{26}$ Redaksi Ensiklopedia, Ensikloped Islam (Jakarta: PT. Intermas, 1994), jilid 4, 154.

${ }^{27}$ Nogarsah Moede Gaya, Buku Pintar Islam, 380.

${ }^{28}$ Makmun Jamaludin, Ramadan Bulan Mulia, 8.

${ }^{29}$ Makmun Jamaludin, Ramadan Bulan Mulia, 10. 
Manusia senantiasa dianjurkan untuk betasbih terutama di bulan Ramadan karena bernafasnya dinilai sebagai tasbih apalagi bernafas sambil mengucapkan tasbih. ${ }^{30}$ Karena yang bertasbih bukan hanya manusia saja akan tetapi makhluk Allah yang lain pun bertasbih. Alquran menjelaskan bahwa tasbih bukan hanya dilakukan oleh manusia. ${ }^{31}$ Tasbih dilakukan oleh segala makhluk Allah. Halilintar bertasbih kepada Allah dengan pujian. Malaikat senantiasa bertasbih kepada Allah. Gunung-gunung bahkan binatang seperti burung dan yang lainnya bertasbih kepada Allah. Sebagaimana firman Allah berikut:

$$
\text { سَبَّحَ لِلَّهِ مَا فِي السَّمَاوَاتِ وَالْأَرْضِ وَهُوَ الَْزَيْزُ الْحَكِيمُ }
$$

"Semua yang berada di langit dan yang berada di bumi bertasbih kepada Allah (menyatakan kebesaran Allah). dan Dialah yang Maha Perkasa lagi Maha Bijaksana”. (Q.S. AlHadid: 1$){ }^{32}$

b. Tidurnya orang yang berpuasa di bulan Ramadan dihitung sebagai ibadah. ${ }^{33}$ Hal ini membuktikan bahwa tidur di selain bulan Ramadan tidak dinilai sebagai suatu ibadah. Tidur hanya sebagai istirahat atau malah berupa sebuah bentuk kemalasan saja. Kalau tidurnya dihitung ibadah apalagi kalau mengurangi waktu tidur. Bulan Ramadan Allah menghitung tidur manusia sebagai ibadah. Sedangkan tidur adalah saudaranya mati. Jadi seharusnya bukan hanya tidur yang menjadi ibadah, mati juga seharusnya menjadi ibadah. Kalau kematian manusia di bulan Ramadan sebagai ibadah, maka bukan hanya tidur yang kita rasakan sebagai kenikmatan tetapi kematian juga. Allah telah berfirman dalam firmannya sebagai berikut:

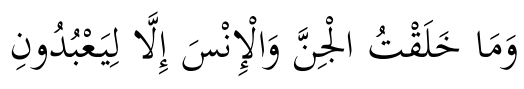

"Dan aku tidak menciptakan jin dan manusia melainkan supaya mereka mengabdi kepada-Ku". (Q.S. Al-Dhariyāt: 56). ${ }^{34}$

\footnotetext{
${ }^{30}$ Fadlilah Ibnu Shidiq al-Qadiri, Mutiara Cinta Rasulullah (Jakarta Selatan: PT. Buku Kita, 2008), 11.

${ }^{31}$ Fadlilah Ibnu Shidiq al-Qadiri, Mutiara Cinta Rasulullah, 13. RI, 2012).

32 Kementerian Agama RI, Alquran dan Terjemahan (Jakarta: Kementerian Agama

${ }^{33}$ Fadlilah Ibnu Shidiq al-Qadiri, Mutiara Cinta Rasulullah, 15. RI, 2012).

${ }^{34}$ Kementerian Agama RI, Alquran dan Terjemahan (Jakarta: Kementerian Agama
} 
Ayat tersebut mengartikan ibadah bukan hanya berupa ritual saja, seperti: salat, puasa, naik haji, membaca Alquran dan berzikir. Akan tetapi yang dimaksud adalah semua yang dilakukan manusia agar menjadikannya sebagai ibadah kepada Allah. Oleh karena itu Islam mengajarkan kepada manusia untuk menjadikan tidur sebagai ibadah kepada Allah.

c. Amalan manusia diterima dan doa-doa dikabulkan. Ramadan adalah waktu yang mustajab bagi doa-doa manusia yang dipanjatkan kepada Allah. Amal-amal saleh yang diterima di sisi Allah itulah yang kita harapkan akan menjadi teman. Karena semua manusia mengharapkan semua doanya dikabul oleh Allah. Akan tetapi ada banyak hal doa untuk dikabul oleh Allah di antaranya adalah khusyuk dalam salat. ${ }^{35}$ Sebagaimana firman Allah:

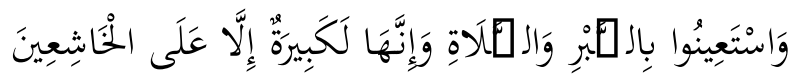

"Jadikanlah sabar dan salat sebagai penolongmu. Dan Sesungguhnya yang demikian itu sungguh berat, kecuali bagi orang-orang yang khusyuk". (Q.S. Al-Baqarah: 45). ${ }^{36}$

Diantara amalan-amalan yang dianjurkan di bulan Ramadan sangatlah banyak, di antaranya adalah sebagai berikut: ${ }^{37}$

1) Puasa. Allah memerintahkan berpuasa di bulan Ramadan sebagai salah satu rukun Islam. Sebagaimana firman Allah sebagai berikut:

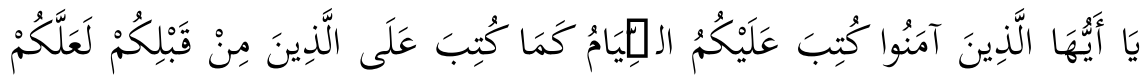

$$
\text { تَتَنَُّونَنَ }
$$

"Hai orang-orang yang beriman, diwajibkan atas kamu berpuasa sebagaimana diwajibkan atas orang-orang sebelum kamu agar kamu bertakwa."(Q.S. Al-Baqarah:183). ${ }^{38}$

Ayat di atas menjelaskan bahwa di bulan Ramadan manusia diwajibkan melaksanakan ibadah puasa. Oleh karena itu, bagi setiap Muslim yang menyaksikan bulan Ramadan maka

\footnotetext{
${ }^{35}$ Makmun Jamaludin, Ramadan Bulan Mulia, 17.

${ }^{36}$ Kementerian Agama RI, Alquran dan Terjemahan (Jakarta: Kementerian Agama RI, 2012).

${ }^{37}$ Ismā‘ $\bar{i} l$ Hanafi, Amaliah Dibulan Ramadan (Bandung: Pustaka Indah, 2008), 24.

${ }^{38}$ Kementerian Agama RI, Alquran dan Terjemahan (Jakarta: Kementerian Agama
} RI, 2012). 
diwajibkan untuknya berpuasa sebulan penuh. Hal tersebut selaras dengan keterangan yang mengatakan bahwa Islam didirikan di atas lima perkara, yaitu bersaksi bahwa tidak ada yang berhak disembah selain Allah dan Muhammad adalah rasul Allah, mendirikan salat, menunaikan zakat, puasa Ramadan, dan pergi ke Baitul Haram. Puasa di bulan merupakan penghapus dosa-dosa yang terdahulu apabila dilaksanakan dengan ikhlas berdasarkan iman dan hanya mengharapkan pahala dari Allah. Sebagaimana Rasulullah bersabda yang artinya: "Barangsiapa yang berpuasa Ramadan karena iman dan mengharap pahala dari Allah, niscaya diampuni dosa-dosanya yang telah lalu'. 39

2) Membaca Alquran. Membaca Alquran sangat dianjurkan bagi setiap Muslim di setiap waktu dan kesempatan. Rasulullah bersabda yang artinya: "Bacalah Alquran, sesungguhnya ia datang pada hari kiamat sebagai pemberi syafaat bagi ahlinya (yaitu, orang yang membaca, mempelajari dan mengamalkannya)". Dan membaca Alquran lebih dianjurkan lagi pada bulan Ramadan, karena pada bulan itulah diturunkan Alquran. Sebagaimana firman Allah:

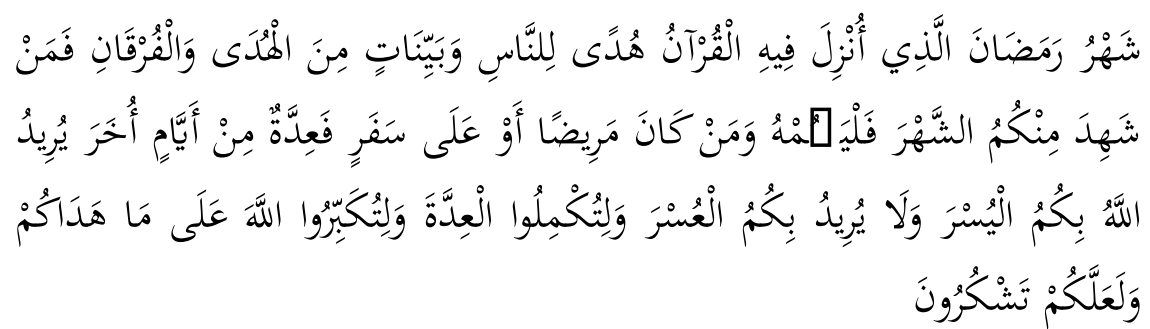

"(Beberapa hari yang ditentukan itu ialah) bulan Ramadan, bulan yang di dalamnya diturunkan (permulaan) Alquran sebagai petunjuk bagi manusia dan penjelasan-penjelasan mengenai petunjuk itu dan pembeda (antara yang hak dan yang bathil). karena itu, Barangsiapa di antara kamu hadir (di negeri tempat tinggalnya) di bulan itu, Maka hendaklah ia berpuasa pada bulan itu, dan Barangsiapa sakit atau dalam perjalanan (lalu ia berbuka), Maka (wajiblah baginya berpuasa), sebanyak hari yang ditinggalkannya itu, pada hari-hari yang lain. Allah menghendaki kemudahan bagimu, dan tidak menghendaki kesukaran bagimu. dan hendaklah kamu mencukupkan bilangannya dan hendaklah kamu mengagungkan Allah atas petunjuk-Nya yang diberikan

${ }^{39}$ Ismā‘ỉ Hanafi, Amaliah Dibulan Ramadan, 27. 
kepadamu, supaya kamu bersyukur. (Q.S: al-Baqarah: $185)^{40}$

Nabi Muhammad selalu memperbanyak membaca Alquran di hari-hari Ramadan, seperti diceritakan dalam hadis 'Aisyah r.a, ia berkata: "Saya tidak pernah mengetahui Rasulullah membaca Alquran semuanya, sembahyang sepanjang malam, dan puasa sebulan penuh selain di bulan Ramadan".

3) Menghidupkan malam-malam bulan Ramadan dengan salat Taperawih berjamaah. Salat Taperawih disyari'atkan berdasarkan hadis 'Aisyar r.a, ia berkata: yang artinya "Sesungguhnya Rasulullah keluar pada waktu tengah malam, lalu beliau salat di Masjid, dan salatlah beberapa orang bersama beliau. Di pagi hari, orang-orang memperbincangkannya. Ketika Nabi mengerjakan salat (di malam kedua), banyaklah orang yang salat di belakang beliau. Di pagi hari berikutnya orang-orang kembali memperbincangkannya. Di malam yang ketiga, jumlah jamaah yang di dalam Masjid bertambah banyak, lalu Rasulullah keluar dan melaksanakan salatnya. Pada malam keempat, Masjid tidak mampu lagi menampung jamaah. Sehingga Rasulullah hanya keluar untuk melaksanakan salat Subuh. Tatkala selesai salat Subuh, beliau menghadap kepada jamaah kaum Muslimin, kemudian membaca syahadat dan bersabda, 'Sesungguhnya kedudukan kalian tidaklah sama bagiku, aku merasa khawatir ibadah ini diwajibkan kepada kalian, lalu kalian tidak sanggup melaksanakannya". Rasulullah wafat dan kondisinya tetap seperti ini. Setelah Rasulullah wafat, syariat telah mantap, hilanglah segala kekhawatiran. Disyari'atkan salat Taperawih berjamaah tetap ada karena telah hilang 'illat (sebabnya), kerena 'illat itu berputar bersama ma'lūl, ada dan tiadanya. Di samping itu, Khalifah Umar telah menghidupkan kembali syari'at salat Taperawih secara berjamaah dan hal itu disepakati oleh semua sahabat Rasulullah ketika itu. ${ }^{41}$

4) Menghidupkan malam Lailatul Qadar: Lailatul Qadar adalah malam yang lebih baik dari pada seribu bulan yang tidak ada Lailatul Qadar dan pendapat paling kuat bahwa ia terjadi di RI, 2012).

${ }^{40}$ Kementerian Agama RI, Alquran dan Terjemahan (Jakarta: Kementerian Agama

${ }^{41}$ Fakhruddin Nursyam, Misteri dan Keajaiban Bulan Ramadan (Surakarta: Ziyad, 2015), 16 . 
sepuluh hari terakhir bulan Ramadan, terlebih lagi pada malammalam ganjil, yaitu malam 21, 23, 25, 27, dan 29. Firman Allah:

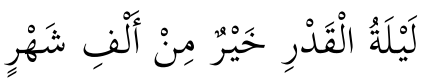

"Malam kemuliaan itu lebih baik dari seribu bulan". (Q.S. AlQadr: 3). ${ }^{42}$

Menghidupkan Lailatul Qadar adalah dengan memperbanyak salat malam, membaca Alquran, zikir, berdo'a, dan membaca selawat.

5) I'tikaf di malam-malam Lailatul Qadar. I'tikaf dalam bahasa adalah berdiam diri atau menahan diri pada suatu tempat, tanpa memisahkan diri. Sedang dalam istilah syar'i, i'tikaf berarti berdiam di Masjid untuk beribadah kepada Allah dengan cara tertentu sebagaimana telah diatur oleh syari'at. I'tikaf merupakan salah satu sunnah yang tidak pernah ditinggal oleh Rasulullah.

6) Memperbanyak sedekah. Rasulullah adalah orang yang paling pemurah, dan beliau lebih pemurah lagi di bulan Ramadan. Hal ini berdasarkan riwayat Ibnu Abbas, ia berkata: yang artinya: "Rasulullah adalah manusia yang paling pemurah, dan beliau lebih pemurah lagi di bulan saat Jibril menemui beliau".

7) Melaksanakan ibadah umrah. Salah satu ibadah yang sangat dianjurkan di bulan Ramadan adalah melaksanakan ibadah umrah dan Rasulullah menjelaskan bahwa nilai pahalanya sama dengan melaksanakan ibadah haji, seperti dalam hadis yang artinya berbunyi: "Umrah di bulan Ramadan sama dengan ibadah haji".

d. Salat sunah menjadi tameng. Rasulullah mengatakan bahwa setiap salat sunah yang dikerjakan di bulan Ramadan akan menjadi jaminan kebebasan manusia dari api Neraka.

e. Salat wajib dilipatkan pahalanya. Salat wajib yang kita tunaikan pahalanya setara dengan tujuh puluh kali salat wajib yang dilaksanakan pada bulan yang lain. Mungkin alasan inilah orangorang meng-qaḍa (mengganti) salatnya di bulan Ramadan.

f. Membaca Alquran dengan pahala yang berlipat. Satu ayat dari Alquran yang dibaca sama nilainya dengan mengkhatamkan Alquran pada bulan yang lain. Dengan adanya bulan yang penuh berkah ini sebagai manusia yang Muslim haruslah memperhatikannya jangan sampai menyia-nyiakan bulan ini. Sebuah keterangan mengatakan RI, 2012).

${ }^{42}$ Kementerian Agama RI, Alquran dan Terjemahan (Jakarta: Kementerian Agama 
andai seorang hamba mengetahui apa yang ada di bulan Ramadan niscaya dia akan menginginkan Ramadan itu sepanjang tahun.

Ramadan juga disebut sebagai bulan kasih sayang. Bulan Ramadan adalah bulan yang penuh rahmat . Pada bulan Ramadan yang mulia manusia berupaya meraih kasih sayang Allah dengan memperbanyak amal-amal saleh. Tetapi bulan yang penuh kasih sayang ini akan menjadi laknat yang luar biasa bagi manusia yang melakukan maksiat. Ramadan adalah bulan ampunan untuk orang-orang Muslim. Ampunan Allah yang ditunjukan bagi orang-orang yang melampaui batas dengan melakukan taubat dan orang Islam yang benar tidak akan meneruskan lagi perbuatan dosanya, karena setiap saat Allah membuka pintu ampunannya terutama pada bulan Ramadan yang disucikan ini. ${ }^{43}$

Asma Allah dalam Asmā' al-Husna yang mengandung dua nama atau dua sifat Allah yang menunjukkan ke Maha pengampunan-Nya adalah alGafär dan al-Gafür. Kedua asma tersebut mempunyai arti yang sama yaitu Maha Pengampun. Sebagaimana telah diketahui bahwa kedua kata Asmā, al-Husna itu berasal dari kata ghafara yang artinya menutupi sesuatu. Jadi kata maghfirah atau ampunan yang diberikan kepada manusia adalah berupa penutupan Allah terhadap dosa-dosa manusia. Dosa itu tidak dihapuskan tetapi ditutupi dan tidak dimintai pertanggung jawaban lagi. ${ }^{44}$

Kata ghafara menurut sebagian pendapat berasal dari kata al-Ghafaru yang mengandung arti sejenis tumbuhan yang digunakan untuk mengobati luka. Sehingga dengan mengambil makna yang kedua, manusia yang beristigfar kepada Allah pada hakikatnya sedang melakukan penyesalan. Dapat dikatakan penyesalan itu menjadi obat pahit yang menyembuhkan dan menghafus dosa-dosa. ${ }^{45}$

Menurut Imam Al-Ghazali bahwa kata Ghafara diartikan dengan kata man azhar al-jamīl wa satar al-Qabïh yang artinya yang menampakkan keindahan dan menyembunyikan keburukan. Keterangan di atas pada hakikatnya menganjurkan kita untuk selalu beristigfar. Terutama pada bulan Ramadan dianjurkan untuk bangun tidur lalu sahur. Akan tetapi bukan hanya sahur saja yang dilakukan waktu itulah dimanfaatkan untuk memohon ampunan kepada Allah. ${ }^{46}$

\section{B. Hadis Keutamaan Bulan Ramadan (Dibelenggunya Setan-setan)}

${ }^{43}$ Fakhruddin Nursyam, Misteri dan Keajaiban Bulan Ramadan, 10.

${ }^{44}$ Fakhruddin Nursyam, Misteri dan Keajaiban Bulan Ramadan, 18.

${ }^{45}$ Fakhruddin Nursyam, Misteri dan Keajaiban Bulan Ramadan, 20.

${ }^{46}$ Fakhruddin Nursyam, Misteri dan Keajaiban Bulan Ramadan, 19-20. 


\section{Analisis Hadis}

Naqd al-sanad (kritik sanad/transmitter) diawali dengan melakukan I'tibar sanad yakni menyertakan sanad-sanad yang lain untuk suatu hadis tertentu, supaya dapat diketahui ada tidaknya periwayat yang lain untuk sanad hadis yang dimaksud. Tujuannya adalah agar terlihat dengan jelas seluruh jalur sanad yang diteliti, nama-nama periwayatnya, dan metode periwayatan yang digunakan oleh masing-masing periwayat yang bersangkutan. ${ }^{47}$ Menurut M. Husein Yusuf, yang dikutip dari Yanuhar Ilyas bahwa Naqd al-Sanad atau kritik sanad merupakan telaah atas prosedur periwayatan (sanad) dari sejumlah perawi yang secara runtut menyampaikan matan hingga perawi terakhir. ${ }^{48}$

I'tibar sanad menghasilkan variasi sanad hadis, kemudian dilanjutkan dengan pembuatan skema seluruh jalur sanad, nama-nama periwayat dan metode periwayatan yang digunakan oleh masing-masing periwayat (tahammul wa al-ada'), setelah itu dilakukan analisis jumlah periwayat. ${ }^{49}$ Menganalisis jumlah periwayat yang akan menghasilkan kuantitas hadis, apakah tergolong mutawattir atau masuk dalam kategori ahad.

Dalam penelitian ini, penulis menggunakan standar mutawattir hadis dari Abu Thayyib. Menurutnya, menentukan sekurang-kurangnya 4 orang karena diqiyaskan dengan banyaknya saksi yang diperlukan hakim untuk memberi vonis kepada terdakwa. ${ }^{50}$ Adanya keseimbangan jumlah antara perawi-perawi dalam thabāqah (lapisan) pertama dengan jumlah perawiperawi dalam thabāqah berikutnya. ${ }^{51}$ Sedangkan hadis ahad adalah hadis yang diriwayatkan oleh perawi dalam jumlah yang tidak banyak, dalam arti tidak sampai jumlah perawi hadis mutawattir. Yakni tiga perawi perthabāqat (disebut hadis mashür), dua perawi per-thabāqat (disebut hadis 'aziz), dan 1 perawi per-thabāat (disebut hadis gharib)..$^{52}$

Jumhur ulama sepakat bahwa beramal dengan hadis ahad yang telah memenuhi ketentuan maqbül hukumnya wajib. Abu Hanifah, Imam Syafi'i dan Imam Ahmad memakai hadis ahad bila syarat-syarat periwayatan yang

${ }^{47}$ Suryadi dan Muhammad Al-Fatih Suryadilaga, Metodologi Penelitian Hadis (Yogyakarta: Teras, 2009), 67.

${ }^{48}$ Yunahar Ilyas dan M. Mas'udi (ed). Pengembangan Pemikiran Terhadap Hadis, 30 .

${ }^{49}$ Yunahar Ilyas dan M. Mas'udi (ed). Pengembangan Pemikiran Terhadap Hadis, 30.

${ }^{50}$ Fatchur Rahman, Ikhtisar Mushthalahul Hadis (Bandung: PT. Alma'arif, 1995), 60.

${ }^{51}$ Fatchur Rahman, Ikhtisar Mushthalahul Hadis, 61.

${ }^{52}$ Endang Soetari, "Pengembangan Syarah dan Kritik Hadis dengan Metode Takhrij”, dalam makalah yang disampaikan dalam seminar nasional studi hadis di UIN Sunan Kalijaga, Yogyakarta, 25 September 2012, 6 
sahịh terpenuhi. Sedangkan golongan Qodariyah dan sebagian ahli Zhahir menetapkan bahwa beramal dengan hadis ahad hukumnya tidak wajib. AlJuba'i dari golongan Mu'tazilah menetapkan tidak wajib beramal kecuali berdasarkan yang diriwayatkan oleh dua orang yang diterima dari dua orang.

Para Ulama hadis seperti Ibn Al-Șalāh, Al-Nawawi (w. 676/1277), Ibn Kathīr, Ibn Hajar al- 'Asqalānī, Jalāl al-Din Al-Suyūti dan lain-lain sudah menjelaskan definisi hadis sahịh. Meskipun ada perbedaan, akan tetapi inti definisi yang dijelaskan mewakili apa yang telah diterapkan oleh Imam AlBukhāri dan Muslim. Definisinya dapat disimpulkan sebagai berikut:

a. Ketersambungan periwayatan

b. Perawi harus adil

c. Semua perawi harus dabit

d. Isnad dan matan harus bebas dari kejanggalan (shadhdh)

e. Isnad dan matan harus bebas dari cacat ('illah). ${ }^{53}$

Berdasarkan definisi atau kriteria ke-sahih -an sebuah hadis tersebut, maka akan diketahui apakah hadis ini dapat diterima atau ditolak. Penelitian kualitas hadis, akan menghasilkan stat us hadis yang mana bisa berupa hadis sahịh, hasan dan da'íf. Hadis yang tergolong dalam kategori sahịh, yaitu apabila suatu hadis telah memenuhi syarat lima di atas. Sedangkan hadis hasan, yaitu hadis yang memenuhi lima kriteria di atas tapi tingkat ke-ḍabitan perawi kurang atau tidak sampai ke derajat sahịh. Sedangkan hadis $\underline{d a}$ 'íf, yaitu suatu hadis yang tidak memenuhi lima kriteria yang telah ditentukan di atas. Bisa karena ada cacat di dalam sanad ataupun matan hadisnya tersebut. ${ }^{54}$

Menurut Syuhudi Ismail, bahwa kejanggalan sanad pada hadis baru dapat diketahui setelah diadakan penelitian sebagai berikut; ${ }^{55}$

a. Semua sanad yang mengandung matan hadis yang mempunyai pokok masalah yang sama, dihimpun dan diperbandingkan.

b. Para periwayat di seluruh sanad dari generasi ke genarasi diteliti kualitasnya.

c. Para periwayat bersifat thiqah dan ternyata ada satu periwayat yang sanadnya menyalahi sanad-sanad lainnya. Maka, sanad yang menyalahi itu disebut sanad shadh sedang sanad-sanad lainnya disebut sanad mahfuz.

53 Kamaruddin Amin, Menguji Kembali Keakuratan: Metode Kritik Hadis, (Jakarta: Hikmah, 2009), hal. 20-21

54 Endang Soetari, Makalah Pengembangan Syarah dan Kritik Hadis dengan Metode Takhrij, 6.

${ }^{55}$ Syuhudi Ismā'ill, Kaedah Keshahihan Sanad Hadis (Jakarta: Bulan Bintang, 1995), 144. 
Kejanggalan hadis terletak pada adanya perlawanan antara suatu hadis yang diriwayatkan oleh perawi yang maqbūl (yang dapat diterima periwayatannya) dengan hadis yang diriwayatkan oleh perawi yang lebih kuat ( $r a ̄ j i h)$ daripadanya, disebabkan kelebihan jumlah sanad dalam ke-ḍabitan. ${ }^{56}$

\begin{tabular}{|c|c|c|}
\hline No. & Rumus Hadis & Matan Hadis \\
\hline 1. & خ، صوم، 0، بدء الخلق 11 & 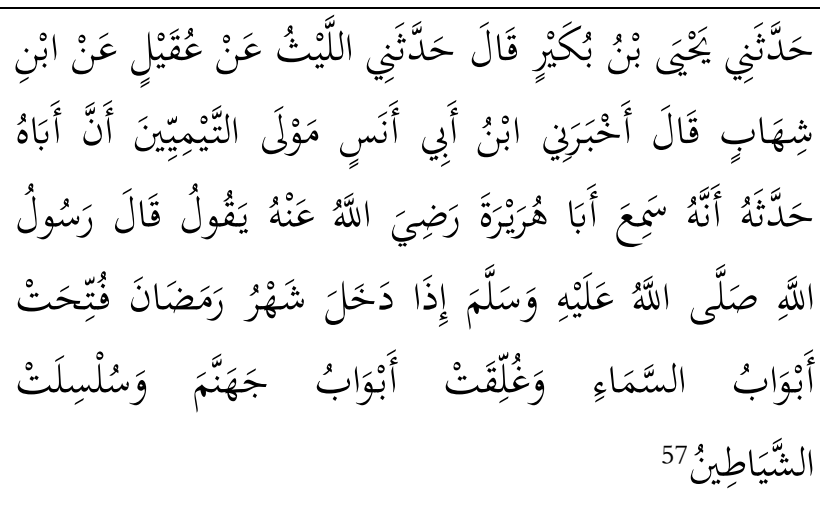 \\
\hline 2. & r,صيام r & 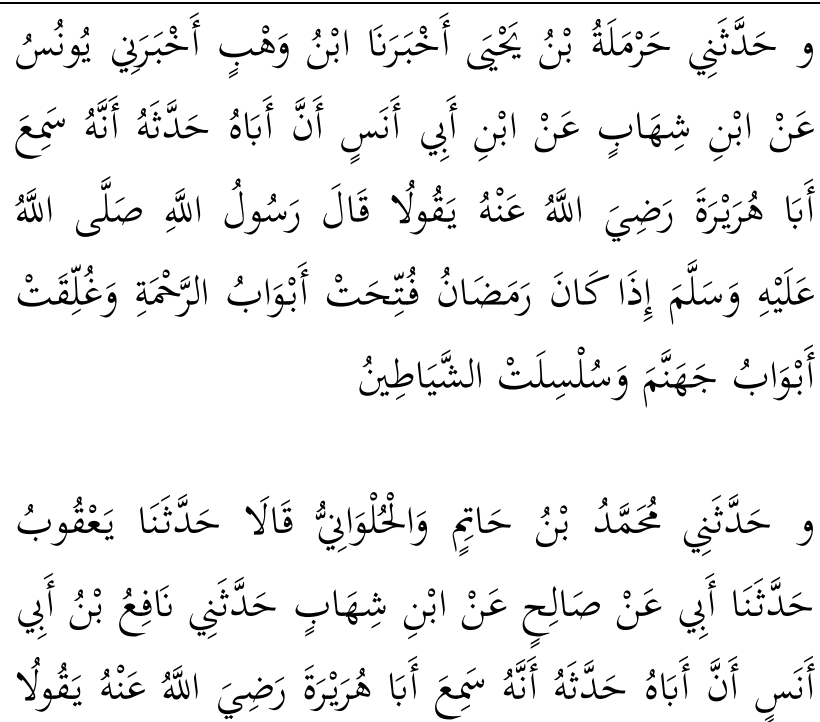 \\
\hline
\end{tabular}
2008), 144.

56 Agus Solahudin dan Agus Suyadi, Ulumul Hadis (Bandung: Pustaka Setia, juz. 1, 227.

${ }^{57}$ Muhammad bin Ismāđìl Al-Bukhārì, Sahịịh al-Bukhārīi (Beirut: Dar al-Fikr, 2005), 


\begin{tabular}{|c|c|c|}
\hline & & 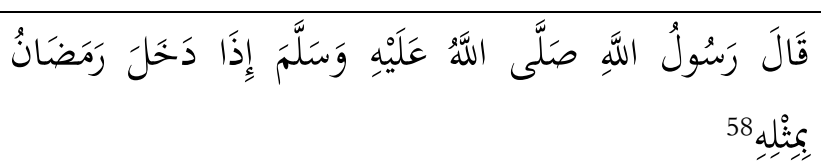 \\
\hline 3. & ن,صيام ع، ه & 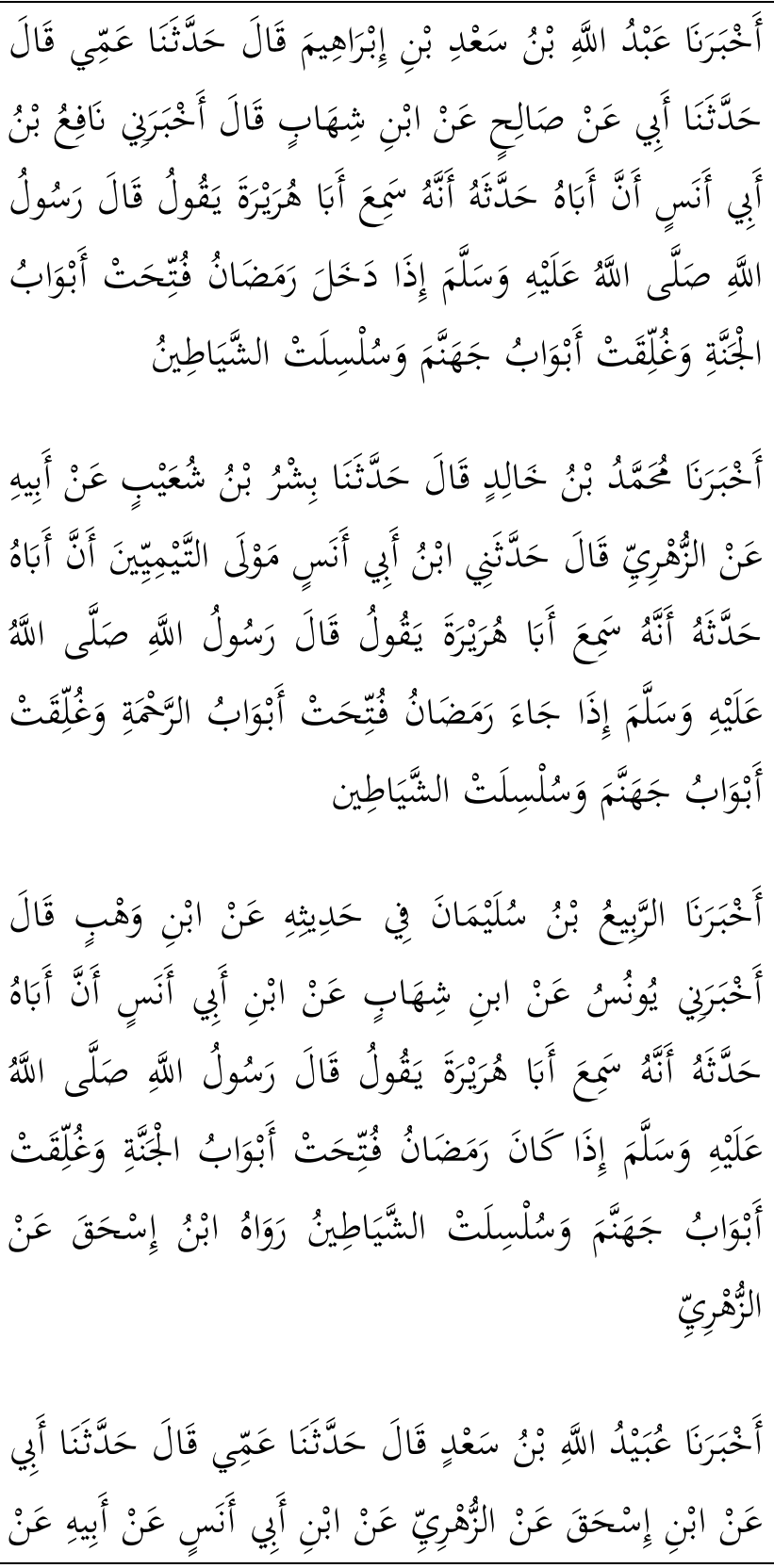 \\
\hline
\end{tabular}

${ }^{58}$ Muslim bin al-Hajjaaj al-Naisabūrí, al-Jāmi’ Al-Sahịḥ (Beirut: Darl Fikr, t.th), juz. 3,121 . 


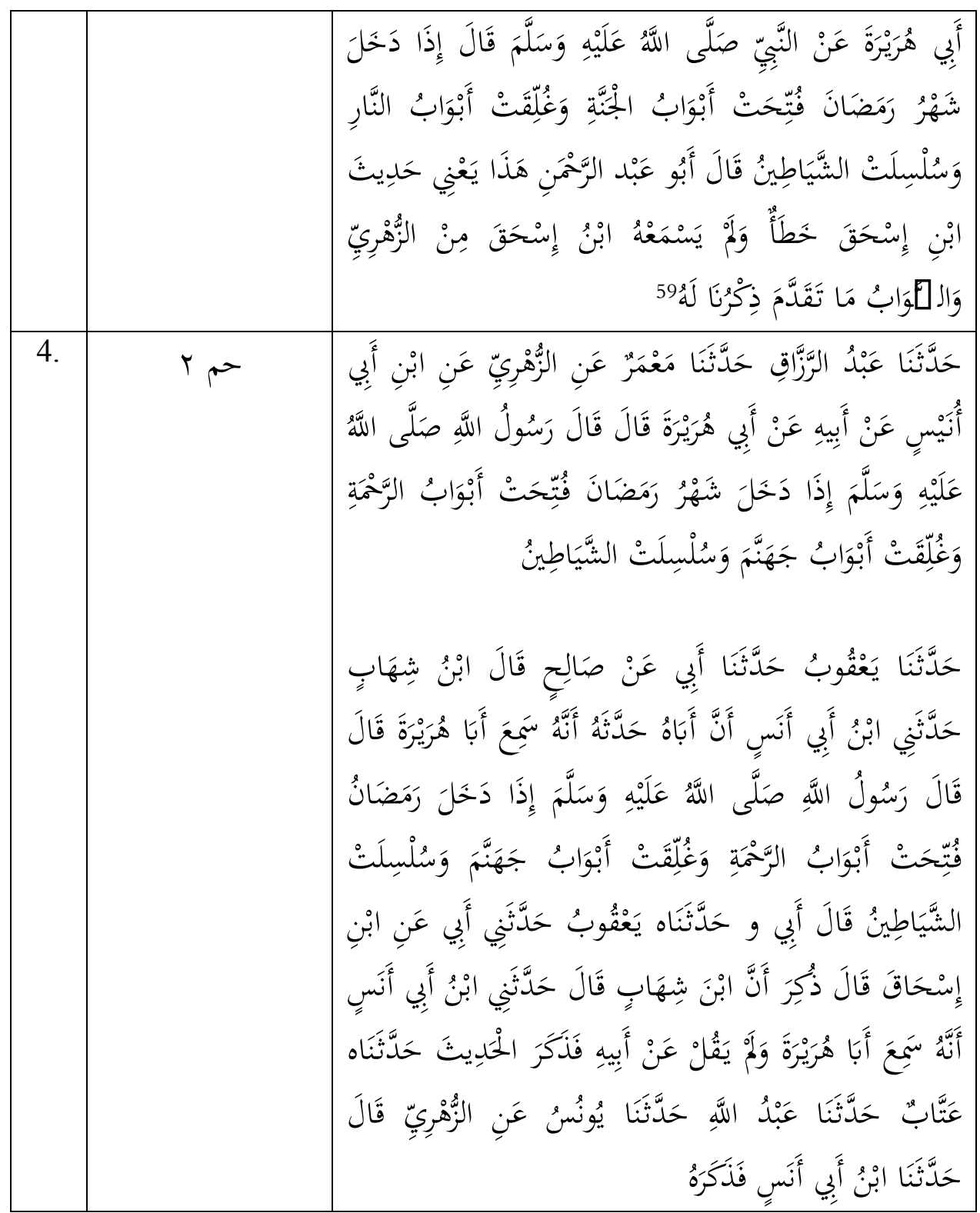

Tabel 1. I'tibar Sanad Keutamaan Bulan Ramadan (Dibelenggunya Setan-setan)

Adapun analisis hadis tentang keutamaan bulan Ramadan dibelenggunya Setan-setan dari segi kuantitas dan kualitasnya adalah sebagai berikut:

a. Analisis Kuantitas Hadis

Megamati dari keseluruhan sanad hadis tentang keutamaan bulan Ramadan di atas, dapat menggambarkan bahwa dari tingkatan șahabi sampai

${ }^{59}$ Ahmad bin Syu'aib, Sunan Al-Nasai (Beirut: Darul Fikr, 2005), juz 4, 129. 
kepada para mukharrij hadis, jumlah perawi yang meriwayatkan hadis keutamaan bulan Ramadan tersebut berbeda-beda dari generasi ke generasi. Ada satu sahabat yang mendengar langsung dari Rasul, yakni Abu Hurairah. Pada generasi selanjutnya yaitu generasi tabi'in, terdapat sepuluh orang perawi yang meriwayatkan hadis tentang keutamaan bulan Ramadan tersebut, sehingga mengindikasikan bahwa hadis tersebut masuk dalam kategori hadis ahad yang 'aziz. Dan pada tabaqat yang ketiga ada delapan belas orang perawi yang meriwayatkannya, kemudian generasi setelahnya ada delapan belas orang perawi dan sampai kepada penulis hadis ada sembilan orang mukharrij, sehingga mengindikasikan kepada kriteria hadis ahad yang gharib. Hal tersebut dikarenakan hadis di atas hanya diriwayatkan oleh seorang sahabat, yaitu Abu Hurairah.

\section{b. Analisis Kualitas Hadis}

Mengamati dari skema sanad dan biografi para perawi hadis tentang keutamaan bulan Ramadan, kesimpulan menunjukkan bahwa semua jalur riwayat dari segi kualitasnya hadis ini termasuk kepada hadis yang sahīh pada awalnya. Dengan alasan karena semua jalur riwayat hadis ini memenuhi kriteria tentang ke-sahihh-an sebuah hadis yang disebutkan di atas. Baik dari dabit, perawinya adil dan ketersambungan sanad, hadis ini terbukti dengan kriteria ini. Kecuali hadis yang diriwayatkan oleh Imam Ahmad, pada skema sanad Imam Ahmad termasuk dalam kategori hadis da'îf dikarenakan terputusnya sanad dari jalur 'Ubaidillah, Ya'qūb, Ibrāhīm, Ibn Ishāq, Ibn Shihab, Ibn Abi Anas. Yang mana seharusnya dari Ibn Abi Anas ke Abu Anas, dalam jalur sanad ini langsung ke Abū Hurairah. Dan juga ada seorang yang di jarh dinilai sebagai sudūq yudallis oleh Ibnu Hajar yaitu Muhammad bin Ishāq. Dengan adanya pen-jarh-an terhadap Muhammad bin Ishāq dengan dinilai lemah dari ke-dabitan-nya. Walaupun terdapat jalur sanad yang cacat akan tetapi hadis ini diperkuat dengan hadis dari jalur lain yakni dari jalur riwayat Imam Al-Nasā'i dan Imam yang lain sehingga derajatnya naik menjadi hadis sahịh li ghairihi.

\section{c. Analisis Matan}

Hadis yang menjelaskan tentang keutamaan bulan Ramadan dibelenggunya Setan-setan mempunyai variasi dalam matannya. Dalam penelitian ini dapat dibuktikan variasi matan hadis tersebut yaitu sebagai berikut:

1) Menggunakan kata سُْْسَِتِ 


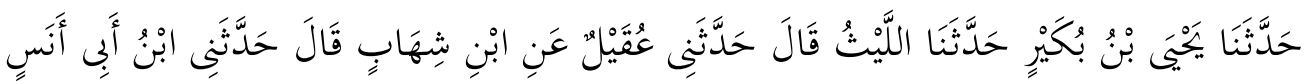

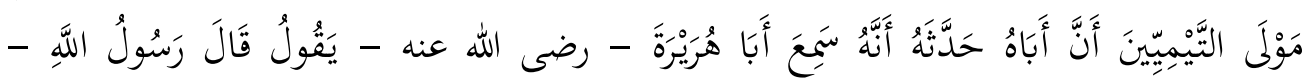

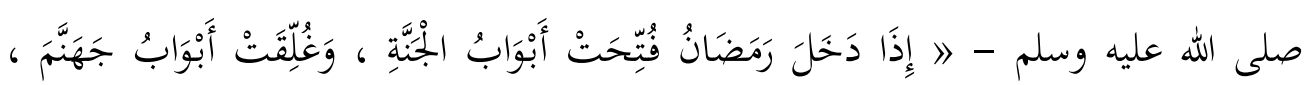

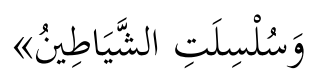

2) Menggunakan kata تُعَلَُْ

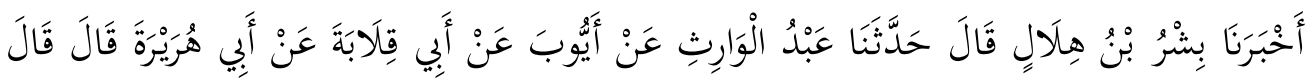

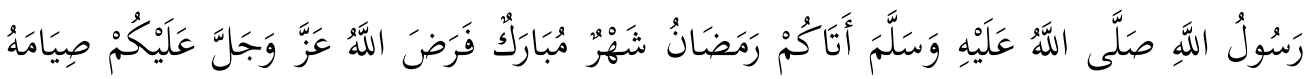

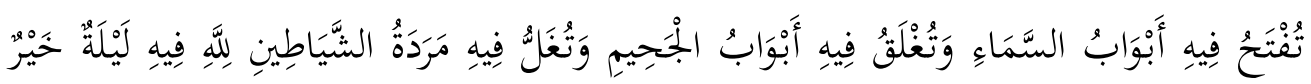

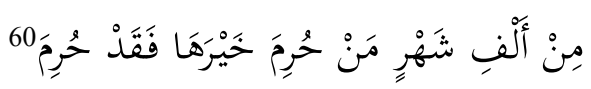

3) Menggunakan kata صُفَِّتَتِ

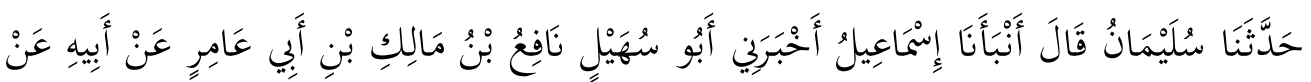

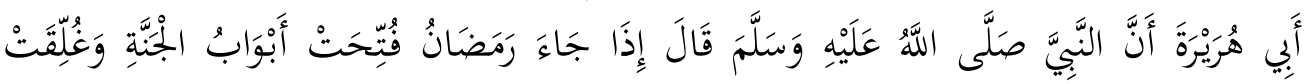

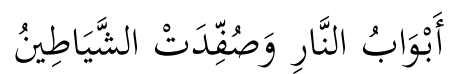

Hasil dari pengamatan dari matan-matan hadis di atas, bahwasannya perbedaan matan hadis tersebut tidak saling bertentangan. Hal ini dapat dibuktikan dengan melihat makna dari matan hadis tersebut. Walaupun hadis yang menjelaskan tentang bulan Ramadan menggunakan variasi matan

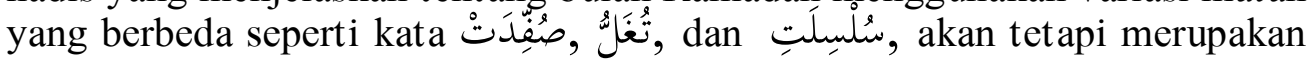
kata yang mutaradif dalam artian kata yang mempunyai makna yang sama (sinonim). Jadi, dapat disimpulkan adanya variasi dalam matan hadis ini tidak saling bertentangan akan tetapi saling menguatkan antara matan hadis yang satu dengan yang lainnya.

\section{Penjelasan Ulama Hadis}

1. Penjelasan Musharrih Tentang Hadis Keutamaan Bulan Ramadan

Menurut bahasa kata syarah hadis diambil dari bahasa Arab, yaitu "sharaha-yashrahu-sharhan" yang mempunyai arti menguraikan atau memisahkan bagian sesuatu dari bagian yang lainnya. ${ }^{61}$ Sedangkan apabila

${ }^{60}$ Ahmad bin Syu'aib, Sunan Al-Nasai, juz 4, 131.

${ }^{61}$ Fatchur Rahman, Ikhtisar Mushtalahul Hadis, 15. 
dikatakan syarah hadis secara mutlak, yaitu penjelasan terhadap ucapan, tindakan, dan ketetapan Rasulullah dengan sanad-sanadnya. ${ }^{62}$

Bulan Ramadan adalah bulan yang penuh dengan limpahan keberkahan dan kebaikan, bulan Ramadan adalah bulan dimana Allah membuka pintu-pintu langit. Peristiwa luar biasa ini semakin mengkukuhkan kemuliaan bulan Ramadan dan menunjukan penghormatan yang besar kepada orang-orang yang berpuasa. ${ }^{63}$ Selain pintu-pintu surga dibuka, di bulan Ramadan juga pintu Neraka dikunci dan Setan-setan dibelenggu. Keterangan ini sesuai dengan sabda Nabi Muhammad sebagai berikut:

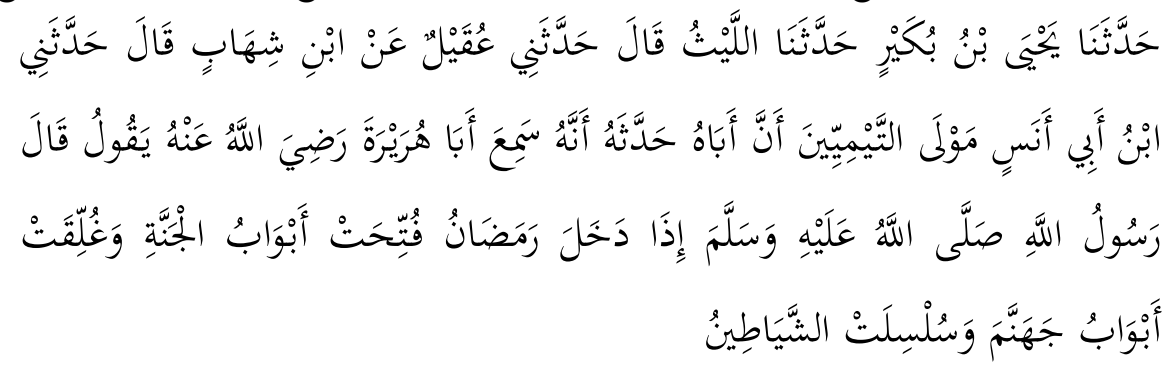

"Telah menceritakan kepada kami Yahya bin Bukair berkata, telah menceritakan kepada saya al-Layth dari 'Uqayl dari Ibnu Shihāb berkata, telah mengabarkan kepada saya Ibnu Abū Anas, maulanya at-Taymiyyin bahwa bapaknya menceritakan kepadanya bahwa dia mendengar Abu Hurairah r.a berkata, Rasulullah Saw bersabda: "Apabila bulan Ramadan datang, maka pintu-pintu langit dibuka sedangkan pintu-pintu jahannam ditutup dan Setan-setan dibelenggu". (HR. Al-Bukhārì)

Hadis di atas menjelaskan bahwa keutamaan bulan Ramadan dengan bulan-bulan yang lain yaitu diantaranya dibuka pintu-pintu langit, ditutup pintu jahanam dan Setan-setan dibelenggu". Adapun penjelasannya dari hadis ini terbagi menjadi dua pendapat yang berbeda :

a. Makna Hakiki Hadis

Makna hakiki adalah penjelasan yang diambil sesuai dengan dhahir hadis tersebut. Menurut pendapat ini, hadis itu menunjukkan bahwa ketika bulan Ramadan pintu surga dibuka, pintu jahanam tertutup dan Setan-setan

${ }^{62}$ Mujiono Nurkhalis, Metodologi Syarah Hadis (Bandung: Fasygil Grup, 2003), 1.

63 Eko Haryanto Abu Ziyad, Memperbaiki Kesalahan dalam Bulan Ramadan, (Jakarta: Islam House, 2009), hal. 19. 
dibelenggu dalam makna yang sebenarnya, yaitu bahwa Setan-setan benar dibelenggu. ${ }^{64}$

Salah satu peristiwa langit yang terjadi di bulan Ramadan adalah terbukanya pintu surga. Semua pintu surga akan terus-menerus dibuka sejak malam pertama hingga malam terakhir bulan Ramadan. Maksud dari terbukanya pintu-pintu surga adalah makna hakiki dan lahirnya dan bisa juga sebagai isyarat melimpahnya pahala pada bulan Ramadan.

Peristiwa gaib selanjutnya yang terjadi di bulan Ramadan adalah ditutupnya pintu-pintu Neraka. Ulama berpendapat bahwa yang dimaksudkan adalah makna lahir dan hakiki, dimana pintu-pintu Neraka ini ditutup sebagai pertanda masuknya bulan Ramadan, sekaligus sebagai pengagungan terhadap kemuliaannya. Selanjutnya maksud dari Setan-setan dibelenggu yaitu sebagaimana keterangan dalam kitab Tanwir al-Hawalik Sharh 'ala Muwata' Malik berikut. ${ }^{65}$

$$
\begin{aligned}
& \text { عن أبي هريرة أنه قال إذا دخل رمضان فتحت أبواب الجنة وغلقت أبواب النار وصفدت }
\end{aligned}
$$

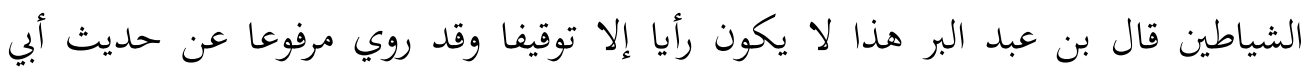

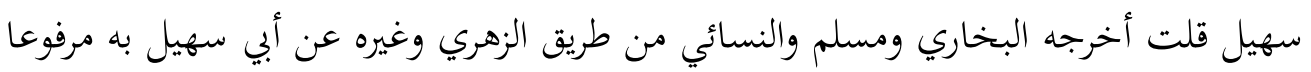

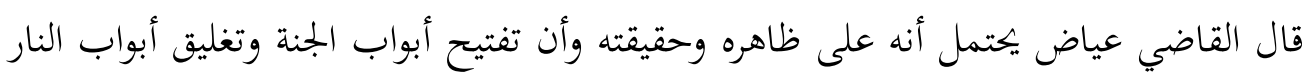

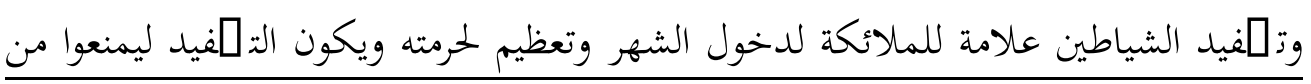$$
\text { إيذاء المؤمنين والتهويش عليهم }
$$

Al-Qađ̣i Iyāọ berpendapat bahwa hadis ini mengandung makna sesuai dengan zhahir dan hakikatnya dari hadis tersebut, dan sungguh dibuka pintupintu surga, ditutup pintu-pintu jahannam dan Setan-setan dibelenggu adalah tanda masuk bulan Ramadan dan mengagungkan kehormatannya, dan dibelenggu menunjukkan bahwa mereka (Setan) terhalang untuk menyakiti orang-orang mukmin dan mengganggu mereka. Selain itu juga ulama berpendapat bahwa "Kalimat Șuffidat as-Shayātīin maknanya shuddat bi alAghlāl (diikat dengan belenggu) agar mereka tidak menggoda orang yang puasa, dan hal itu menjelaskan bahwa pada bulan Ramadan kebanyakan orang yang asik dalam kelaliman bersuci diri dari dosa-dosa dan bertobat kepada Allah Ta'ala. Keterangan ini membuktikan bahwa Setan-setan dibelenggu secara hakikatnya bukan sekedar kiasan.

${ }^{64}$ Software Maktabah Syamilah, Tanwir al-Hawalik Syarh 'ala Muwatha' Malik, 222.

${ }^{65}$ Software Maktabah Syamilah, Tanwir al-Hawalik Sharh 'ala Muwata' Mālik. 
Bulan Ramadan adalah bulan dimana Setan-setan dibelenggu. Akan tetapi pada bulan Ramadan masih banyak manusia yang melakukan maksiat. Maka maksud dari Setan-setan dibelenggu ini dijelaskan dalam kitab Umdah al-Qāri Sharh Șahịh al-Bukhāri sebagai berikutt ${ }^{66}$ :

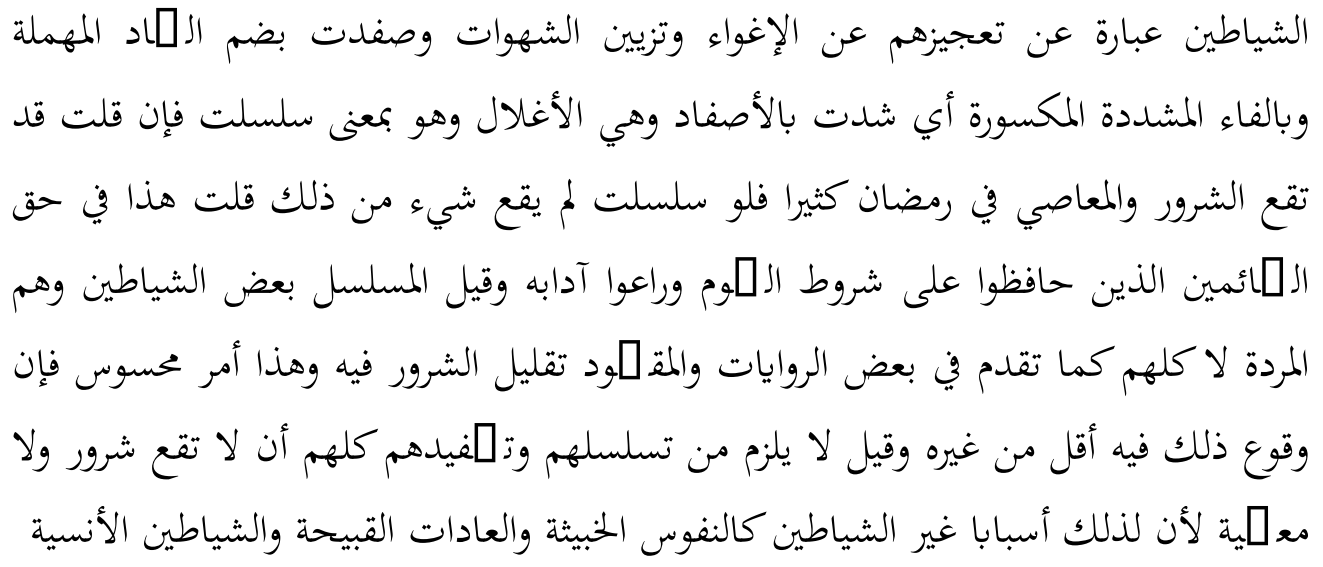

Setan selalu menghiasi syahwat manusia, kata shufidat di sini mempunyai makna Syuddat bilafsad atau bil Aglal yang maknanya diikat dengan dibelenggu. Akan tetapi "Jika dikatakan, 'Banyak terjadi kejahatan dan kemaksiatan di bulan Ramadan, padahal jika Setan dibelenggu hal itu seharusnya tidak terjadi? Jawabannya adalah Setan-setan (dibelenggu) terjadi pada hak orang-orang yang melaksanakan saum, yang memenuhi syarat-syaratnya dan memelihara adab-adanya. Dan ada pula yang berpendapat bahwa semua Setan dibelenggu itu tidak memastikan tidak terjadinya kejahatan dan kemaksiatan karena hal itu terdapat sebab-sebab lain selain godaan Setan, seperti jiwa yang jahat, kebiasaan yang jelek, dan Setan-setan jenis manusia. Sebagaimana firman Allah berikut :

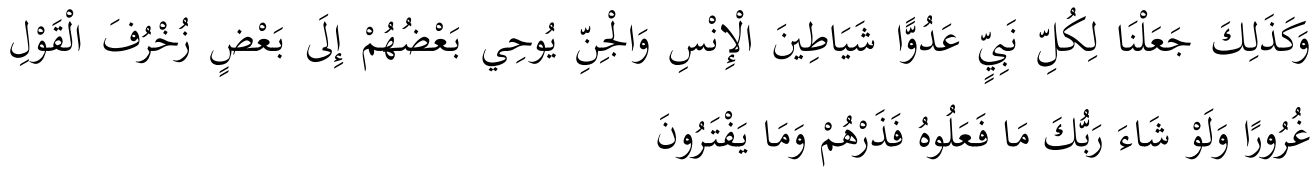

"Dan demikianlah Kami jadikan bagi tiap-tiap Nabi itu musuh, Yaitu syaitan-syaitan (dari jenis) manusia dan (dan jenis) jin, sebahagian mereka membisikkan kepada sebahagian yang lain perkataan-perkataan yang indah-indah untuk menipu (manusia). Jikalau Tuhanmu menghendaki, niscaya mereka tidak

${ }^{66}$ Software Maktabah Syamilah, Umdah al-Qari Sharh Șạịh al-Bukhārī. 
mengerjakannya, Maka tinggalkanlah mereka dan apa yang mereka ada-adakan. Maksudnya syaitan-syaitan jenis jin dan manusia berupaya menipu manusia agar tidak beriman kepada Nabi”. (Q.S. Al-An'am: 112).

\section{b. Makna Majazi Hadis}

Makna majazi adalah makna yang dijelaskan tidak dengan makna aslinya atau hakikatnya, akan tetapi dengan makna kiasan. Hadis tentang keutamaan bulan Ramadan ini sebagian ulama memaknainya dengan makna majazi. Pemaknaan dari pintu-pintu langit dibuka ini hanya kiasan saja. Bahwa yang dimaksudkan adalah kiasan dari turunnya rahmat dan dihilangkannya sekat-sekat yang menghalangi naiknya amalan para hamba. Kadang dengan pencurahan taufik, sehingga amal baik terasa mudah dilakukan dan terkadang dengan penerimaan yang baik. Keterangan lain juga berpendapat bahwa yang dimaksud pintu-pintu langit adalah pintu-pintu surga, dengan dalil bahwa yang disebutkan setelah itu adalah pintu-pintu Neraka. Dalam hal ini tidak ada pertentangan. Karena pintu-pintu langit akan mengantarkan para hamba menuju surga yang berada di atas langit dan atapnya adalah Arsh Rabb uyang maha penyayang. ${ }^{67}$

Penjelasan pintu-pintu surga dibuka yaitu merupakan kiasan ungkapan dari berbagai ketaatan yang dibuka oleh Allah untuk hambahambanya pada bulan Ramadan yang menjadikan sebab-sebab yang mengantarkan mereka masuk surga. Selanjutnya makna dari pintu-pintu Neraka ditutup yaitu dikiaskan kepada penjelasan bahwa manusia memutuskan diri dari berbagai kemaksiatan dan meninggalkan berbagai amalan yang mengantarkan manusia kedalam Neraka. Dan juga karena Allah tidak banyak menjatuhkan hukuman terhadap hamba-hambanya atas perbuatan dosa yang dilakukan. Selain itu juga ulama berpendapat bahwa ditutupnya pintu-pintu Neraka adalah banyaknya ampunan dan pemaafan terhadap dosa-dosa. ${ }^{68}$

Makna selanjutnya yaitu Setan-setan dibelenggu, yang dimaksud dengan kalimat ini adalah sebagaimana penjelasan dibawah ini: ${ }^{69}$

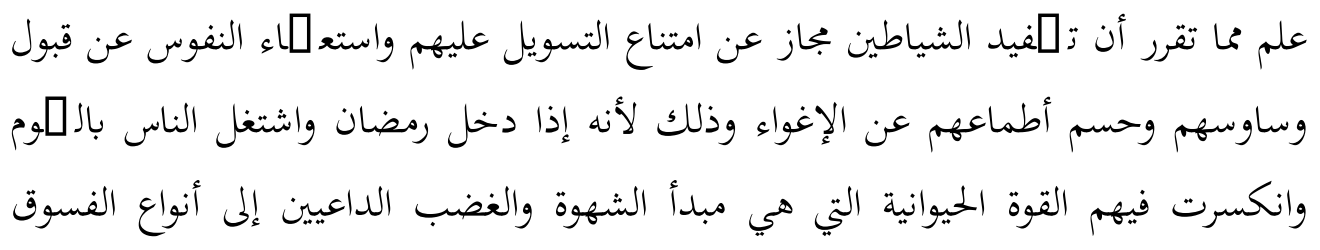

${ }^{67}$ Fakhruddin Nursyam, Misteri dan Keajaiban Bulan Ramadan, 27- 44.

${ }^{68}$ Fakhruddin Nursyam, Misteri dan Keajaiban Bulan Ramadan, 27- 44.

${ }^{69}$ Software Maktabah Syamilah, Faid al-Qadir Sharh al-Jami' al-Sagir, juz 1, 471. 


$$
\begin{aligned}
& \text { وفنون المعاصي وصفت أذهاغم واشتغلت قرائحهم وصارت نفوسهم كالمرائي المتقابلة المتحاكية } \\
& \text { وتنبعث من قواهم العقلية داعية إلى الطاعات ناهية عن المعاصي فتجعلهم بجمعين على } \\
& \text { وظائف العبادات عاكفين عليها معرضين عن صنوف المعاصي عائقين عنها فتفتح لهم أبواب }
\end{aligned}
$$

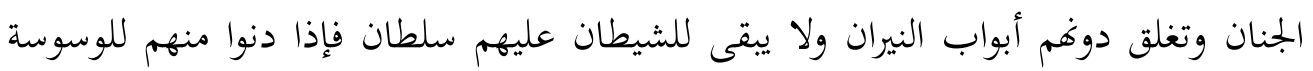

$$
\begin{aligned}
& \text { يكاد يحرقهم نور الطاعة والإيمان }
\end{aligned}
$$

Keterangan di atas menjelaskan bahwa telah diketahui dari makna yang telah ditetapkan bahwa Setan-setan dibelenggu itu bermakna kiasan, yaitu Setan tidak dapat menggoda manusia dan begitu juga jiwa manusia yang tidak dapat menerima godaan dari Setan-setan serta memutuskan ketamakan Setan terhadap bujukan. Hal itu karena apabila datang bulan Ramadan, orang-orang disibukkan dengan puasa. Nafsu hewani sebagai sumber syahwat dan emosi yang menyeru kepada macam-macam kefasikan dan kemaksiat telah lemah pada diri manusia. Selain itu, akal manusia telah jernih, tabiatnya sibuk dengan ibadah. Jiwa manusia seperti cermin yang saling berhadapan lagi saling mengikat, dan terpancar dari kekuatan akal sebagai pendorong kepada ketaatan dan pencegah dari kemaksiatan.

Kekuatan-kekuatan seperti di atas itu menjadikan manusia bersatu dalam melaksanakan ibadah dan selalu istiqamah. Selain itu juga manusia dapat berpaling dari berbagai macam maksiat dan membenci kemaksiatan tersebut. Maka terbukalah pintu-pintu surga, tertutup pintu-pintu Neraka, dan Setan tidak berdaya atas perbuatan manusia yang baik. Adapun jika Setan mendekati untuk menggoda, hampir saja cahaya taat dan keimanan membakar Setan-setan itu. ${ }^{70}$

Hadis yang menerangkan tentang keutamaan bulan Ramadan sangat banyak sekali, akan tetapi dalam hal ini penulis mengambil satu hadis yang mana kandungan hadisnya adalah bahwa di bulan Ramadan semua pintupintu surga dibuka, pintu-pintu Neraka ditutup, dan Setan-setan dibelenggu. Hadis ini mengandung dua makna yaitu makna hakiki dan makna mazaji sebagaimana telah dijelaskan di atas. Dalam hal ini penulis memberikan pendapat bahwa dalam pemaknaan hadis tersebut lebih setuju dengan pemaknaan secara dahir dari hadis, tidak menggunakan kiasan. Karena pada hakikatnya pendapat yang menjelaskan bahwa pintu-pintu surga dibuka, pintu Neraka ditutup dan Setan-setan dibelenggu itu benar terjadi secara

${ }^{70}$ Software Maktabah Syamilah, Faid al-Qadir Sharh al-Jami' al-Sagīi, juz 1, hal. 437-438. 
dzahirnya. Sebab kalau dikiasakan tidak ada faktor kedaruratan untuk memelingkan kata dari makna lahirnya. ${ }^{71}$

2. Variasi Kalimat dalam Matan Hadis Keutamaan Bulan Ramadan (Dibelenggunya Setan-setan)

Hadis yang menerangkan tentang keutamaan bulan Ramadan yang dikaji penulis terdapat suatu kalimat dalam matan hadis yang berbeda akan tetapi maknanya sama. Kalimat tersebut yaitu sufidat al-Shayātin, Sulsilat al-Shayạtịn, dan Tughallu al-Shayạtịn. Sebagaimana terdapat dalam hadis berikut:

a. Hadis Riwayat Al-Bukhāri

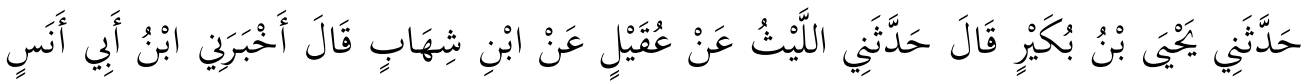

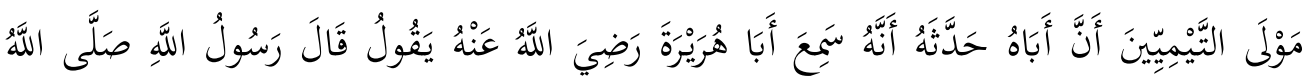

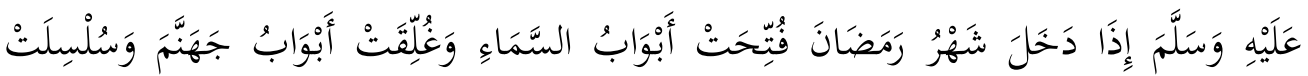
الشنََّّاطِينُ

b. Hadis Riwayat Muslim

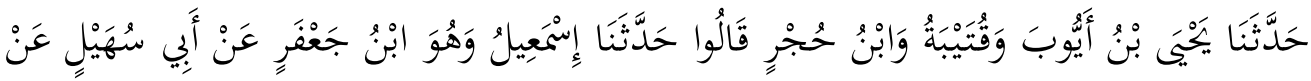

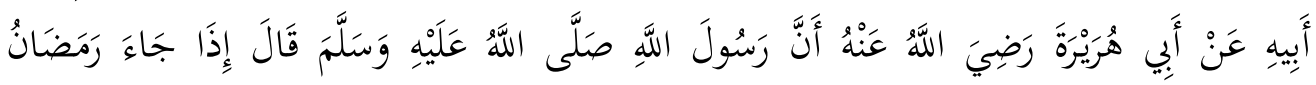

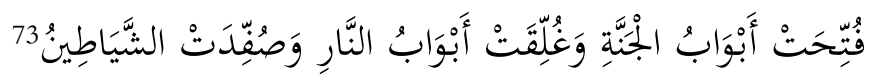

c. Hadis Riwayat An-Nasai

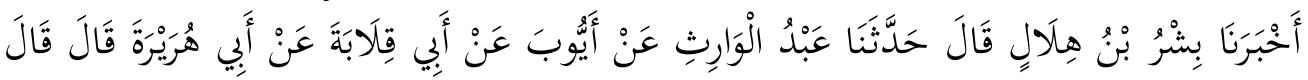

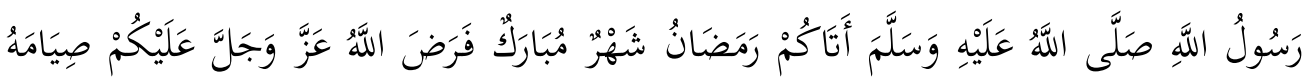

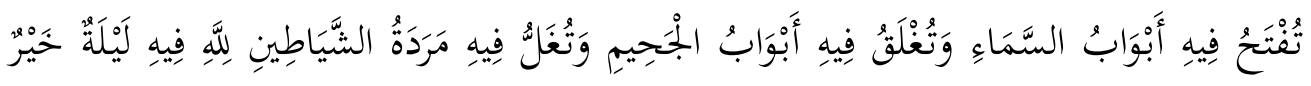

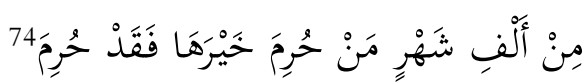

Adanya variasi kalimat dalam matan sebenarnya sudah hal biasa, adapun penjelasan dari kata safd, sebagaimana dijelaskan dalam kitab AlFaiq fí Gharīb al-Hadis berikut ini:

${ }^{71}$ Software Maktabah Syamilah, Fathul Bari, 245.

${ }^{72}$ Muhammad bin Ismā'ìl Al-Bukhārì, Sahịị al-Bukhārī, juz. 1, 227.

${ }^{73}$ Muslim bin al-Hajjaaj al-Naisabūri, al-Jämi' al-Sahịh, juz. 3, 121.

${ }^{74}$ Ahmad bin Syu'aib, Sunan Al-Nasai, juz 4, 131. 
أى قيدت يقال : صفده وصفله وأصفده. صفد والا]فد والآفاد : القيد ومنه قيل للعطية

صفد لأها قيد للمنعم عليه 75

Kata șafd, șafad, dan șafād pada dasarnya mempunyai makna qayd (mengikat), maka dari makna itu suatu pemberian ('atiyyah) disebut șafad karena pemberian itu mengikat orang yang menerimanya.

Selanjutnya kata sulsilat dan tughallu mempunyai makna yang sama dengan kata Șafd yaitu mengikat. Hal ini dijelaskan dalam kitab $s$ \} iyam min Sharh Al-Tirmidhi sebagai berikut:

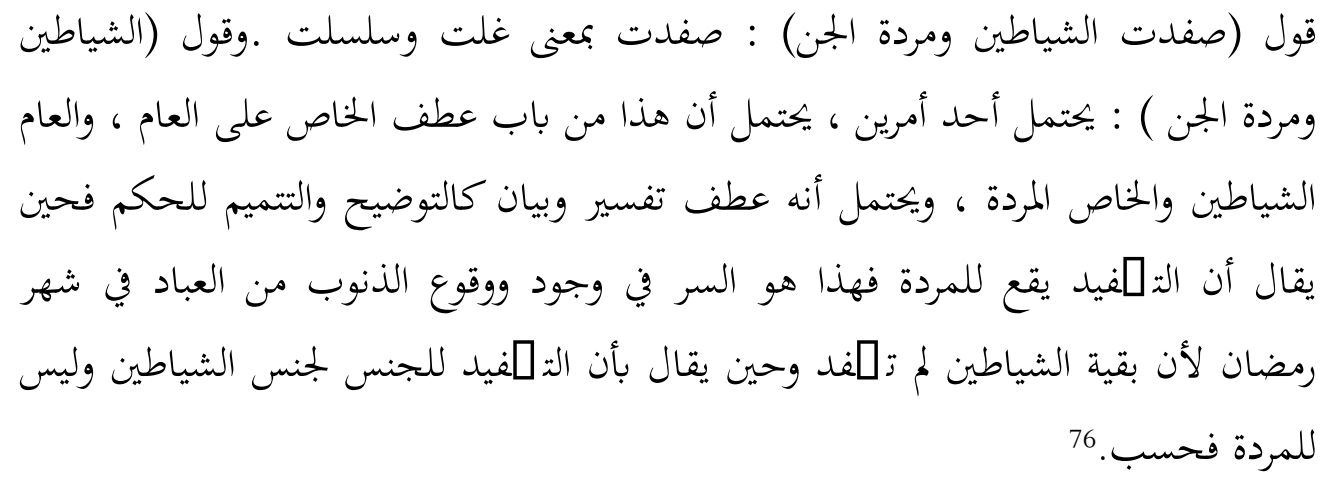

Syarah hadis di atas menjelaskan bahwa kata safd pada kalimat suffidat al-Shayātin pada dasarnya mempunyai makna sama dengan ghalla (membelenggu) dan salsala (merantai). Oleh karena itu dapat disimpulkan bahwa ketiga kata ini disebut kalimat yang mutaradif (mempunyai makna yang sama). Jadi, kalimat șuffidat al-Shayätīn dapat dimaknai shuddat bi alAșfad (diikat dengan belenggu). Selain ketiga kata tersebut di sini dijelaskan tentang kata Setan. Struktur kalimat yang terdapat dalam hadis ini termasuk dalam 'at af al-Khaș 'ala al-'Am (menghubungkan kata khusus kepada kata umum). Kata umum yang dimaksud adalah al-Shayätin (Setan-setan) dan kata khusus adalah maradah al-Jinn (jin-jin yang jahat). Hal ini menjelaskan bahwa semua Setan dibelenggu. Selanjutnya struktur kalimat diatas juga bisa termasuk ke dalam 'ataf tafsiri atau 'ataf bayan yang mana kata maradah al-Jinn sebagai penjelas dari kata shayätīn. Keterangan ini menunjukkan bahwa yang dibelenggu hanya Setan yang jahat saja.

${ }^{75}$ Software Maktabah Syamilah, Muhammad bin Umar Al-Zamakhsyari, al-Fa'iq fi Gharib al-Hadith, 302.

${ }^{76}$ Software Maktabah Syamilah, Muhammad Sulaiman bin Nasir a-Ulwan, Sharah Kitab Siyam Min Sunan Al-Tirmidhi, juz 1, 9. 


\section{SIMPULAN}

Hadis-hadis tentang keutamaan bulan Ramadan dalam menjelaskan terbelenggunya setan-setan secara kualitas hadisnya adalah sahịh li ghairihi. Adapun dari segi kuantitasnya hadis ini termasuk hadis ahad gharíb.

Adapun pemaknaan hadis dapat ditinjau dari dua segi. Pertama, makna hakiki, bahwa pintu surga dibuka, neraka ditutup dan setan-setan dibelenggu merupakan kenyataan secara hakikatnya. Dan kedua, makna majazi, bahwa pintu surga dibuka, neraka ditutup dan setan-setan dibelenggu merupakan makna kiasan, tidak dalam kenyataan.

\section{DAFTAR PUSTAKA}

'Itr, Nuruddin. Ulumul Hadis. Bandung: Remaja Rosdakarya, 2012.

Abu Ziyad, Eko Haryanto. Memperbaiki Kesalahan dalam Bulan Ramadan. Jakarta: Islam House, 2009.

Ahmad bin Syu'aib. Sunan Al-Nasai. Beirut: Darul Fikr, 2005.

Amin, Kamaruddin. Menguji Kembali Keakuratan: Metode Kritik Hadits. Jakarta: Hikmah, 2009.

Bashori, Lutfhi. Musuh Besar Islam. Jakarta: LPPI, 2006.

Al-Bukhārī, Muhammad bin Ismā'cill. Saḥịh al-Bukhārī. Beirut: Dar al-Fikr, 2005.

Dewan Redaksi Ensiklopedi Islam. Ensiklopedi Islam. Jakarta: PT. Intermas, 1999.

Gaya, Nogarsah Moede. Buku Pintar Islam. Jakarta: Ladang Pustaka dan Intimedia, t.th.

Glasse, Cyrill. Ensiklopedia Islam. Jakarta: Rajawali Press, 1999.

Hanafi, Ismāî̀i. Amaliah Dibulan Ramadan. Bandung: Pustaka Indah, 2008.

Ilyas, Yunahar dan Muhammad Mas'ud. Perkembangan Pemikiran Terhadap Hadis. Yogyakarta: LPPI, 1996.

Ismā‘īl, Syuhudi. Kaedah Keshahihan Sanad Hadis. Jakarta: Bulan Bintang, 1995.

Jamaludin, Makmun. Ramadan Bulan Mulia. Bandung: CV. Kurnia Asih, $2011 .$.

Kementerian Agama RI. Alquran dan Tafsir. Jakarta: Kementerian Agama RI, 2012.

Kementerian Agama RI. Alquran dan Terjemahan. Jakarta: Kementerian Agama RI, 2012.

Khozin, Ahmad Abdul. Pengantar Ulumul Hadis. Cirebon: STAI BBC, 2012. Al-Naisabūrī, Muslim bin al-Hajjaj. al-Jāmi' Al-Saḥịh. Beirut: Darl Fikr, t.th.

Nurkhalis, Mujiono. Metodologi Syarah Hadis. Bandung: Fasygil Grup, 2003. 
Nuruddin, Azhari. Bulan Ramadan Yang Dirindukan. Bandung: Pustaka Cempaka, 2015..

Al-Qadiri, Fadlilah Ibnu Shidiq. Mutiara Cinta Rasulullah. Jakarta Selatan: PT. Buku Kita, 2008.

Rahman, Fatchur. Ikhtisar Mushthalahul Hadis. Bandung: PT. Alma'arif, 1995.

Redaksi Ensiklopedia. Ensiklopedi Islam. Jakarta: PT. Intermas, 1994.

Salim, Amr Abdul Mun'im. Taysir Ulum al-Hadis lil Mubtadi'in. Kairo: Maktabah Ibnu Taymiyah, 1997.

Ash-Shiddieqy, Teungku Muhammad Hasbi. Sejarah dan Pengantar Ilmu Hadis. Semarang: Pustaka Rizqi Putra, 1999.

Shihab, M. Quraish. Yang Tersembunyi. Lentera Hati: Jakarta, 2000.

Soetari, Endang. "Pengembangan Syarah dan Kritik Hadis dengan Metode Takhrij", dalam makalah yang disampaikan dalam seminar nasional studi hadis di UIN Sunan Kalijaga, Yogyakarta, 25 September 2012.

Software Maktabah Syamilah.

Solahudin, Agus dan Agus Suyadi. Ulumul Hadis. Bandung: Pustaka Setia, 2008.

Suryadi dan Muhammad Al-Fatih Suryadilaga. Metodologi Penelitian Hadis. Yogyakarta: Teras, 2009.

Suryadilaga, Muhammad Alfatih. Aplikasi Penelitian Hadis. Yogyakarta: Teras, 2009.

Syarifudin, Ahmad. Puasa Menuju Sehat Fisik dan Psikis. Jakarta: Gema Insan, 2003.

Umar, Nasarudin. Jihad. Tebet Barat: Mata Air Publising, 2006. 